\title{
The Sedimentary Record of Paleogene Sequences in Sarawak, Malaysia
}

\author{
Franz L. Kessler ${ }^{1, \#}$, John Jong ${ }^{2}$, Mazlan Madon ${ }^{3}$ \\ ${ }^{1}$ Goldbach Geoconsultants O\&G and Lithium Exploration, Glattbach, Germany \\ 2JX Nippon and Gas Exploration (Malaysia) Limited, Kuala Lumpur, Malaysia \\ ${ }^{3}$ Department of Geology, University of Malaya, Kuala Lumpur, Malaysia \\ \#Corresponding author, franzlkessler32@gmail.com
}

\begin{abstract}
In this paper, we compare the oldest Tertiary sedimentary sequences in the southern margin of the South China Sea based on outcrop and well data along the Sarawak margin, northern Borneo. Paleogene rocks in Sarawak are present in three tectono-stratigraphic zones and represent three depositional settings. Outcrops and deep exploration wells in the Miri Zone indicate shelfal clastics, carbonates, and claydominated neritic sediments. In the Sibu Zone (Rajang Fold-Thrust Belt), Late Cretaceous to Late Eocene deep marine clastic-sediments indicate a shallowing upward of the depositional basin, which was later buried to great depths (?) and metamorphosed. In the Kuching Zone, the Kayan and Plateau sandstones represent a fluvial-dominated non-marine depositional setting. There are two major unconformities within the Paleogene of Sarawak: the Rajang Unconformity, dated as approximatively $37 \mathrm{Ma}$, and the younger nearTop Eocene (a.k.a. Base Oligocene) unconformity of 33.7 Ma. The likely presence of Eocene strata in the margins of Sundaland is associated with an early phase of regional extensional tectonism, which was also observed in the Penyu and Malay basins, offshore Peninsular Malaysia, and is probably related to the onset of rifting of the South China Sea continental crust.
\end{abstract}

Keywords: Eocene, Oligocene, northern Borneo, Sarawak, Stratigraphy, South China Sea.

\section{INTRODUCTION}

The north-western portion of Borneo Island is part of Sundaland, which represents the southeastern corner of the Eurasian continental plate. Terrane analysis reveals that Sundaland is made up of a number of terranes or micro-plates originating from the northern Gondwanaland, which rifted, drifted, and amalgamated in the Late Paleozoic and Mesozoic. Occupying the position of active continental margin, Sundaland has recorded the history of the growing and slivering of a continent by accretion and dispersion, respectively (Satyana,
2003). Following a period of rifting and amalgamation (Savva et al., 2014), the South China Sea (SCS) opened in a scissor-shape manner and offers an image of the rifting structures, which varies along strike of the basin margins. The SCS has a long history of extension, which dates back from the Late Cretaceous, and allows us to observe an early stretching on the northern margin onshore and offshore South China.

Sarawak, the topic of this paper, lies on the southern shoulder of the SCS scissor graben. Here we observe Eocene and Oligocene sediments, which 
are the oldest unmetamorphosed sedimentary deposits in the margins of the SCS, often deeply buried under Late Oligocene and Miocene deposits such as those observed in the Penyu, Malay and West Natuna basins (e.g., Burton and Wood, 2010; Kessler et al., 2020), and some show signs of profound diagenetic imprint (Maga et al, 2015; Kessler and Jong, 2018). In a previous paper (Kessler et al., 2020), we described Paleogene sequences based on data from Penyu Basin (PB) and Malay Basin (MB), off the east coast of Peninsular Malaysia at the westernmost part of the present-day South China Sea. The continental margins around the SCS, in geological terms, are areas of thinned continental crust overlain by Paleogene-Neogene clastic and carbonate sedimentary sequences on extended and subsided pre-Tertiary basement. They are the result of a complex interplay of crustal extension, basin subsidence, erosion and uplift of mountain ranges (e.g., Kessler and Jong, 2016). Most data points on the deeper Eocene-Oligocene sedimentary section are derived from outcrops and oil and gas exploration wells located predominantly in the nearshore areas, and some onshore, with only few penetrations in the central SCS. Gravity and seismic studies point to varying thickness of sediment in discrete depocentres, the deepest of which exceeds a thickness of $10,000 \mathrm{~m}$, such as in the Baram-Champion Delta region.

The southern margin of the SCS (or Sarawak/Sabah margin) is also dissected by several major lineaments, e.g., Baram Line, Jerudong Line, Lupar Line systems etc., along which transpressive movements are believed to have occurred. Structural movements took place during Oligocene and Miocene times, and the direction of movement may have flipped due to changes in intra-plate stress patterns.
In northern Sarawak (in the Miri Zone of Haile, 1974), data from exploration wells and outcrops indicate a continental margin setting, in which the Paleogene sequences were mostly deposited under fully marine conditions. In some areas of blockfaulting and sedimentary basin (e.g., Tatau area), however, the oldest sediments are composed of conglomeratic sequences. Further to the south and southeast, a tectonic contact is assumed between the essentially nearshore-shallow marine formations of the Miri Zone and the deep marine turbidites in the fold and thrust belt of the Rajang Group.

Our knowledge of the Late Cretaceous to Eocene Rajang Group is mostly based on outcrop data, but unfortunately outcrops are scattered over large areas and are mostly poorly dated and/or correlated. Despite these shortcomings, facies analysis has been carried out in the Belaga Formation, which forms the most prominent member of the Rajang Group. The Belaga facies show a close association of debris flow and turbidity flow deposits within a steeply dipping and highly folded succession. Similar sandbody types and facies associations were also observed in the West Crocker Formation of NW Sabah. Detailed studies on the Belaga Formation have been carried out by various authors to characterise the facies and sandbody types for a better understanding of the Rajang deep marine depositional system (e.g., Zainol et al., 2007; Galin et al., 2017; Kuswandaru et al., 2018). In the southernmost corner of Sarawak, geologically called the Kuching Zone (Haile, 1974), we find again Paleogene sediments, but here in fluvial facies.

In this paper, we attempt to describe the existing (known) data points (Figure 1), explore major unconformities related to regional deformation events and their possible correlation along the Sarawak margin. 


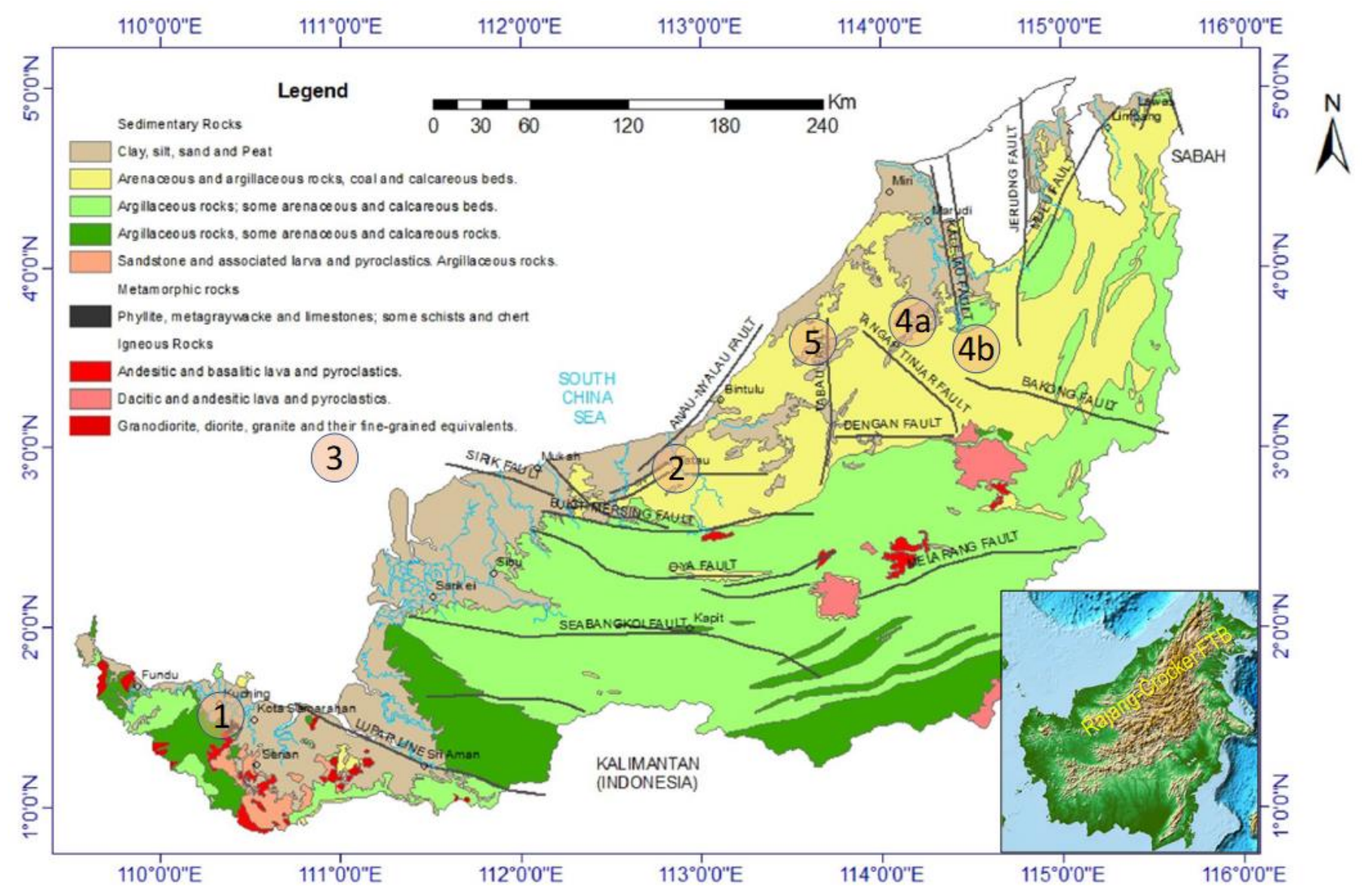

Figure 1: Lithologic map of Sarawak modified after Adepehin et al. (2019), serving as location index. Annotated are the investigated areas with Paleogene deposits - (1) Kayan and Plateau sandstones (Kuching Zone), (2) Rajang Group, Tatau (Sibu Zone), (3) Nuang-1, offshore Mukah/Tatau (Half Graben Province), (4a) Engkabang/Karap Anticline (Miri Zone), (4b) Batu Gading (Miri Zone), (5) Batu Niah Subis Limestone and Subis2 (Miri Zone). Inset is the topography map of Borneo with location of Rajang Fold Thrust Belt annotated.

\section{STUDY OBJECTIVE AND DATABASE}

In Sarawak, we note significant and puzzling differences in Eocene/Oligocene sediment characteristics, and as a result, their lateral contiguity and spatial relationships are far from obvious. The objective of the study is to compare the Eocene-Oligocene sequences in the southern margin of SCS, primarily in Sarawak and to relate and discuss their tectonic and paleogeographic implications on the evolution of the southern SCS margin. This paper summarizes selected pre- and Early Oligocene data mostly from onshore Sarawak. Here, the data are predominantly related to geological outcrops and a couple of offshore and coastal exploration wells (Figure 1).

\section{GEOLOGICAL SETTING OF SARAWAK}

The geological subdivisions of the Sarawak region comprise four main tectono-stratigraphic zones: West Borneo Basement, Kuching Zone, Sibu Zone, and Miri Zone (Haile, 1974; Hutchison, 1989; Madon, 1999) (Figure 2a). Figure 2b shows the generalised stratigraphic columns of these tectonostratigraphic provinces. A brief description of regional geological setting and the investigated Paleogene localities along Sarawak margin are given below.

\section{West Borneo Basement}

The West Borneo Basement is the Pre-Tertiary continental core of Borneo and is believed to be the 
eastwards extension of Sundaland (Hutchison, 1989), and is formed by the Schwaner Mountains in Indonesian East Kalimantan (Figure 2a). The geology of this structural province has been summarised by Hutchison (1989, p. 181; 1996, p. 252-253). Earlier research indicated the oldest rocks are Middle-Upper Carboniferous to Permian metamorphic rocks (mica schists, hornfels and metaquartzites). However, recent work by HenningBreitfeld et al. (2020) based on U-Pb dating suggests that the rocks are no older than Triassic; and the metamorphics were derived from Cretaceous volcaniclastics. These rocks are intruded by Middle Jurassic to Late Cretaceous plutonic suites comprising quartz diorite, tonalite, granite, some gabbro, diorite, and norite.

\section{Kuching Zone}

The Kuching Zone is likely the northward extension of the West Borneo Basement into Sarawak, and the geology of this zone was studied by Tan (1982)
(Figure 2a). Cretaceous granitoids intruded the Cretaceous and older rocks. All these rocks are overlain unconformably by terrestrial and marine siliciclastic rocks of Late Cretaceous to Middle Miocene age that crop out extensively in the western and eastern parts of the region. Examples include the deposits of Paleogene intermontane basins - the Kayan and Plateau sandstones (Figure $2 b)$.

The eastern boundary between the Kuching and Sibu zones is marked by the Lupar Line, a NWtrending zone of melange (Lubok Antu Melange), which is overlain by flysch-like deepwater clastic sediments of the Lupar Formation, which are interbedded with pillow basalt and intruded by gabbro. The Lubok Antu Melange consists of sandstone, radiolarian chert, basic igneous rocks, and limestone in shear mud matrix, and has been interpreted as a tectonic melange formed during the Eocene by Tan (1982) and Haile et al. (1994). The Lupar Formation is apparently overlain by the

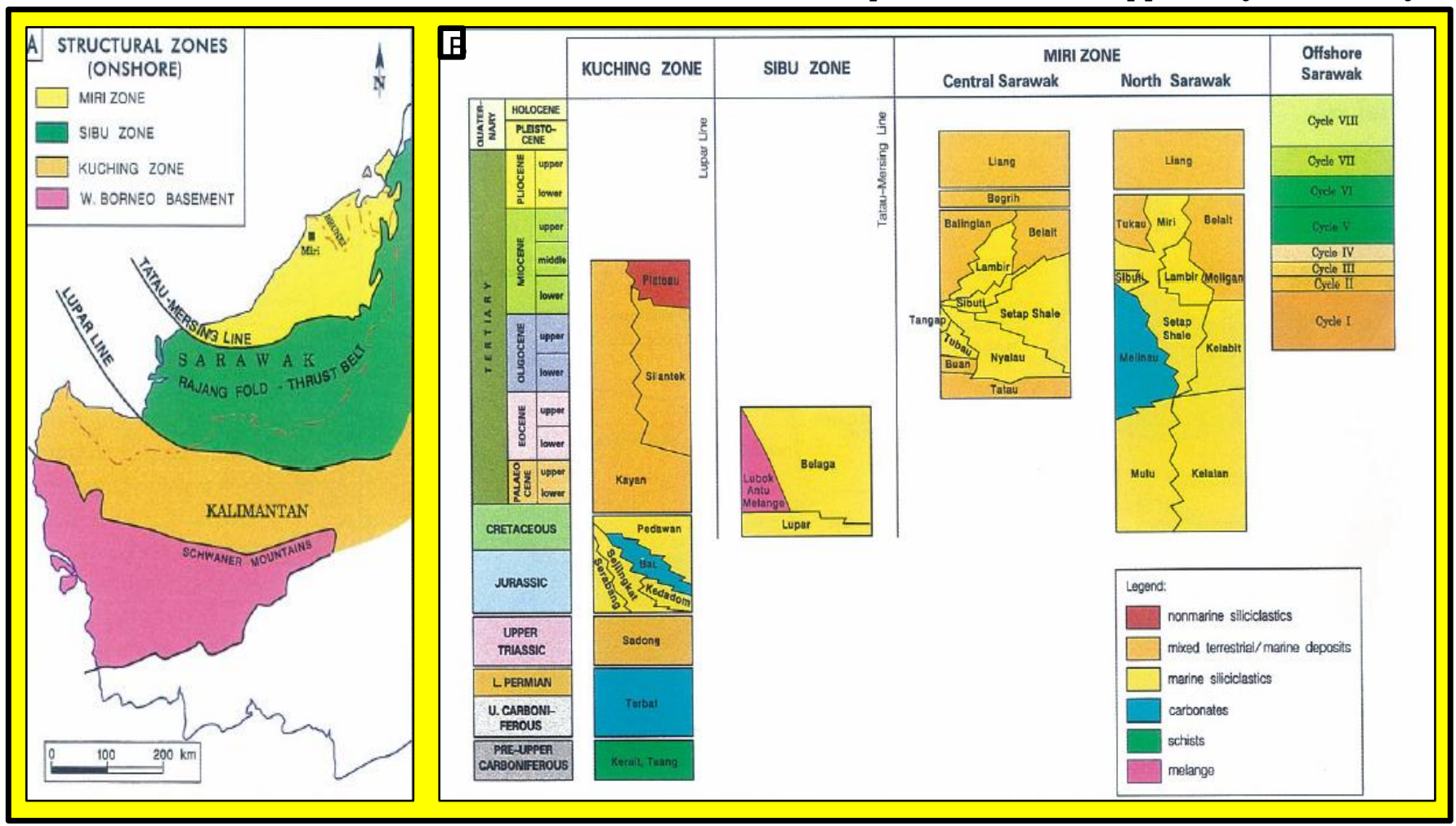

Figure 2: (A) Onshore structural subdivision of Sarawak and Kalimantan (Indonesian Borneo). From Madon (1999) and after Liechti et al. (1960). (B) Generalised stratigraphic columns for onshore structural provinces of Sarawak and correlation with offshore sedimentary cycles. From Madon (1999) and modified after Geological Survey of Malaysia (1995). 
basal member of the Belaga Formation (Rajang Group), which forms the Sibu Zone.

\section{Sibu Zone}

The Sibu Zone is underlain predominantly by the Rajang Group (Figure 2a), which consists of intensely folded, thrusted, and low-grade metamorphosed Late Cretaceous to Eocene turbidites, with radiolarian chert, spilite, and dolerite (Haile, 1969). The Rajang Group includes the Lupar and Belaga Formations of West Sarawak (Figure 2b). The Belaga Formation has been dated using foraminifera as Upper Cretaceous to Upper Eocene (Wolfenden, 1960), and forms a large outcrop belt almost $200 \mathrm{~km}$ wide and continues eastwards in a crescentic trend into Sabah as the Sapalut, East Crocker, and Trusmadi formations (Madon, 1999). Outliers of the overlying OligoMiocene Nyalau Formation also occur within the Sibu Zone, such as in the Usun Apau area.

\section{Miri Zone}

The boundary between the Sibu Zone and the Miri Zones is represented by the Tatau-Mersing Line (Figure 2a), a structurally complex zone consisting of Palaeocene to Eocene ophiolitic rocks, including spilite, basalt, tuff and radiolarian chert (Hutchison, 1989). The feature is also aligned with a major Late Eocene unconformity between the Belaga, Mulu and Kelalan formations (Rajang Group) and overlying Upper Eocene-Recent sediments of the Miri Zone (Figure 2b). This Late Eocene Unconformity represents a major phase of tectonism that deformed the deep marine rocks of the Rajang Fold-Thrust Belt. Overlying these deformed rocks are Oligo-Miocene deltaic-marine to neritic sediments that crop out in central Sarawak (Tatau, Nyalau, Setap, and younger formations). Further to the northeast, similar shallow water Miri, Lambir and Tukau Formations can be logged. The Oligo-Miocene sediments are predominantly siliciclastics except for isolated outcrops of carbonates such as the Melinau Limestones (Figure 3). The Batu Gading and Batu Niah are investigated examples of such carbonate outcrops located in the Miri Zone.

\section{EOCENE TO LATE OLIGOCENE SEQUENCES IN SARAWAK}

Discussed below are the Paleogene sequences observed along the Sarawak margin, starting from southwest to northeast, displaying an overall trend of decreasing stratigraphic and structural complexity.

\section{Kayan and Plateau Sandstones (Kuching Zone)}

In Hutchison (2005), Upper Cretaceous to Eocene sand-rich clastic deposits form plateaus in the greater Kuching area (also called the Kuching Zone). The latter is radically different from younger Rajang Group deposits and the Tertiary clastic and carbonate realms of Central Luconia and the Baram Delta.

- According to Breitfeld et al. (2018), the Kuching Zone in West Sarawak consists of two different sedimentary basins, the Kayan and Ketungau basins (Figure 3). The sedimentary successions in the basins are part of the Kuching Supergroup that extends into Kalimantan. The uppermost Cretaceous (Maastrichtian) to Lower Eocene Kayan Group forms the sedimentary deposits directly above a major unconformity. They consist of the Kayan and Penrissen sandstones and are dominated by fluvial channels, alluvial fans and floodplain deposits, with some deltaic to tidally-influenced sections in the Kayan Sandstone (Figure 3c). The Kayan Sandstone 


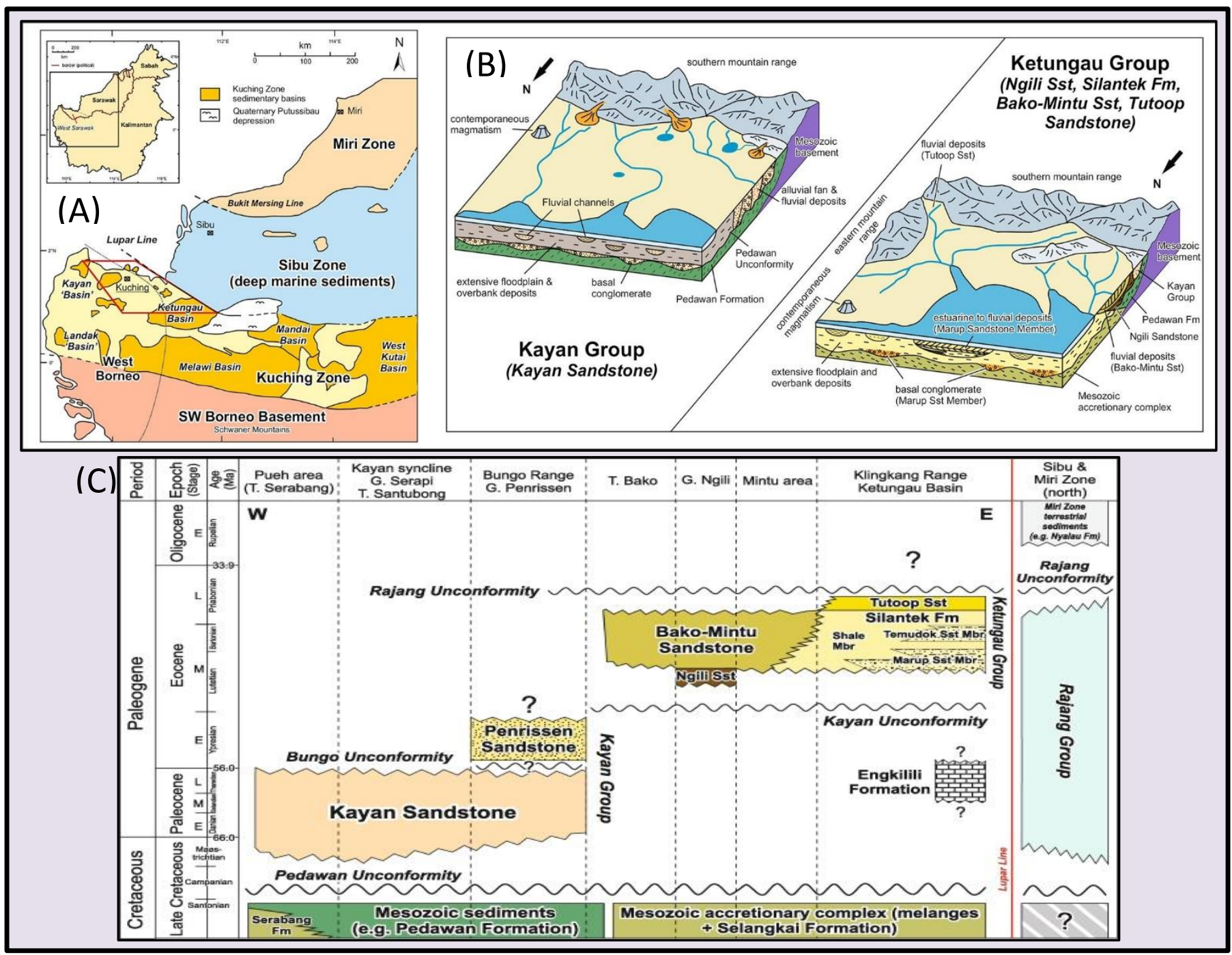

Figure 3: (A) The structural zones of onshore Sarawak with sedimentary basins of the Kuching Zone. The study area is displayed in the red box. (B) Schematic models showing the depositional environments of the Kayan and Ketungau groups, their stratigraphic context, and their interpreted source regions (not to scale). (C) Stratigraphy of the uppermost Cretaceous to Late Eocene sedimentary deposits of the Kuching Zone that form the Kayan and Ketungau groups, and their relationship to the underlying formations. From Breitfeld et al. (2018).

(Uyop et al., 1996) consists predominantly of thick-bedded to massive cross-bedded sandstone, conglomerate and siltstone, which is characteristic of a fluvio-deltaic environment of deposition. It overlies with an angular unconformity the marine Pedawan Formation (Upper Jurassic-Upper Cretaceous) (Banda, 1999). North of Bau, the Pedawan Formation is predominantly argillaceous, consisting of carbonaceous shale and mudstone, while the Kayan Sandstone is characterized by arenaceous materials of fine- to mediumgrained cross-bedded sandstone and conglomerate. Muller (1968) made an extensive palynological study and proposed several palynological zonations based on the occurrence of palynomorphs recovered from Cretaceous-Eocene sediments of West Sarawak.

- In the late Early or early Middle Eocene, sedimentation in this basin ceased and a new basin, the Ketungau Basin, developed to the East (Breitfeld et al., 2018). This change is marked by the Kayan Unconformity (Figure 3c). Sedimentation resumed in the Middle Eocene (Lutetian) with the marginal marine, tidal to deltaic Ngili Sandstone and Silantek 
Formation. Up sequence, the Silantek Formation is dominated by floodplain and subsidiary fluvial deposits. The Bako-Mintu Sandstone, probably a lateral equivalent of the Silantek Formation, is formed of major fluvial channels. The top of the Ketungau Group in West Sarawak is formed by the fluviallydominated Tutoop Sandstone. This shows a transition of the Ketungau Group in time towards terrestrial/fluvially-dominated deposits (Figure 3c). Paleocurrent measurements show river systems were complex but reveal a dominant southern source. This suggests uplift of southern Borneo initiated in the region of the presentday Schwaner Mountains from the latest Cretaceous onwards. The sediments of the Kuching Supergroup are predominantly horizontal or dip at low angles and form large open synclines. Steep dips are usually restricted to fault zones, such as the Lupar Line.

- Within the Lubok Antu Mélange (Liechti et al., 1960; Hutchison, 2005), the Engkilili Formation crops out in a belt of $15 \times 3 \mathrm{~km}$, and forms a mélange of calcareous claystone with large limestone blocks. The limestone blocks yielded a good foraminifera fauna of Palaeocene to Middle Eocene age (Tan, 1979). Until now it is not known where these allochthonous blocks have originated from, but arguably may have been derived from a now missing carbonate sequence originally deposited as time equivalents northeast of the Kayan sandstone areas.

Nonetheless, the stratigraphic and tectonic relationships between the greater Lubok Antu, and the Kayan and Plateau sandstones, and the Rajang Group remain poorly understood. It is worth mentioning that the published outcrops of the
Bako Sandstone by Johansson (1999), which outcrop in the Bako Peninsula in the Kuching Division and extend into the South China Sea, warrant further investigation, to determine if they provide further support for the presence of Eocene strata along the studied Sarawak margin. Currently, the evidence for the age of the Bako sandstones is rather vague (possibly Upper Cretaceous to Eocene; Johannson, 1999) and this formation is therefore excluded from the study.

\section{Rajang Group (Sibu Zone)}

The Rajang Group is a several thousand meters thick sequence of Late Cretaceous to Eocene deepmarine turbidite deposits that occupy a large swath of northern Borneo, known as the Sibu Zone (Haile, 1974; Galin et al., 2017) (Figure 2a). The Rajang is thought to represent remnants of an accretionary prism, composed of turbidites, uplifted and eroded in Late Eocene time (Sarawak Orogeny, Hutchison, 1996; marked by the great unconformity, termed Rajang Unconformity by Breitfeld et al., 2018). The Sibu Zone is often also referred to as the "Rajang Group Fold-Thrust Belt", in reference to the fold and thrust structures due to the orogenic deformation that left an arcuate mountainous area extending from West Kalimantan to the northern tip of Borneo. Due to its complexity of folding and thrusting, there exists no complete accepted stratigraphic column. There are quite a few, but mostly isolated outcrops distributed over a large area. The Rajang Group is important in the context of the SCS Eocene evolution, given it contains intervals of Early Eocene age. The base of the Rajang Group deposits is poorly exposed and understood, and the question remains whether the Rajang Group is in-situ or at least partly allochthonous.

In tectonic terms, the Rajang Group (exposed in Sarawak, and Sabah where it is called Crocker 


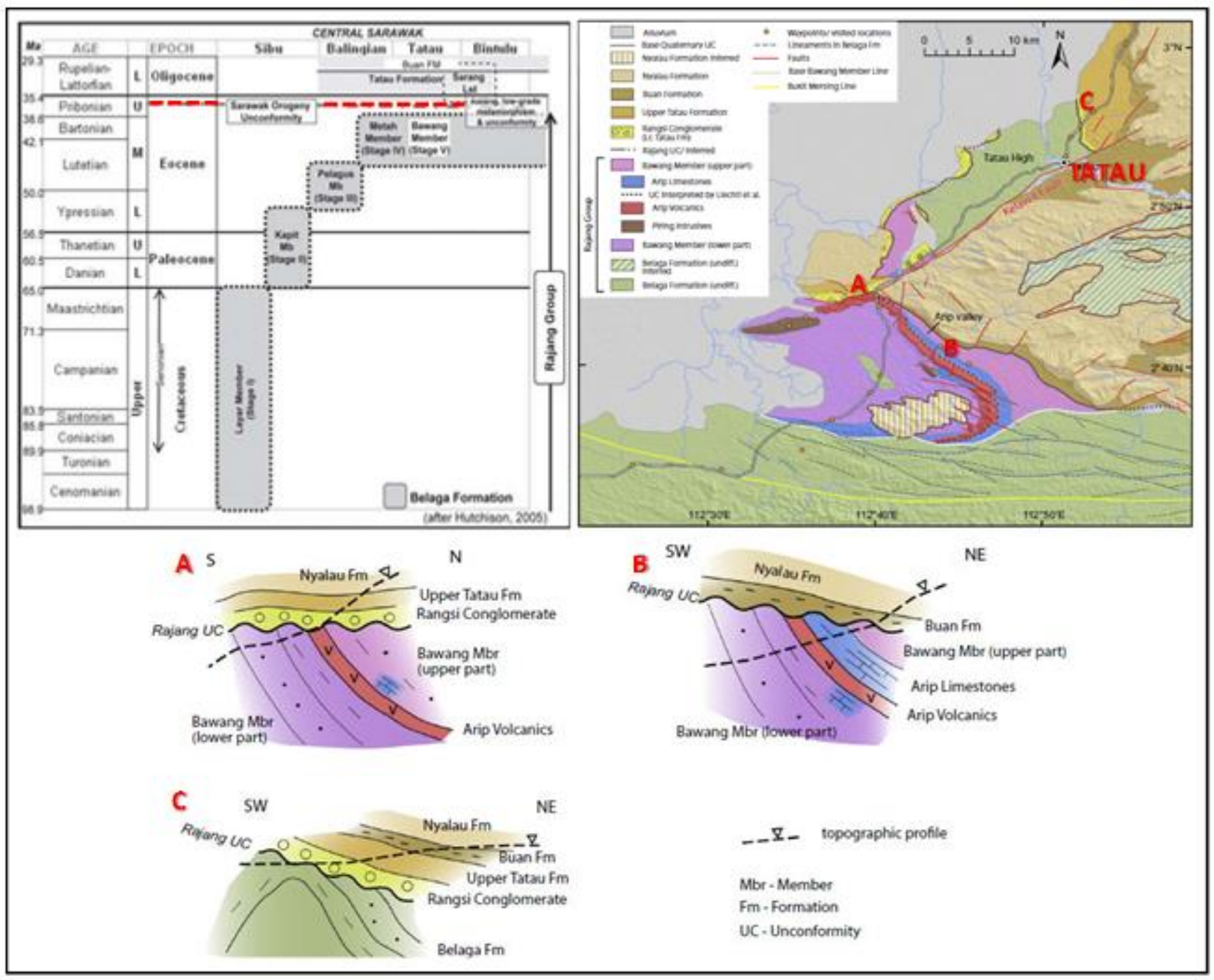

Figure 4: (Top left) Chronostratigraphic table showing sub-division of Belaga Formation, Rajang Group in Tatau area, Central Sarawak (from Hutchison, 2005), the red dashed line represent the Rajang Unconformity, associated with the Sarawak orogeny. (Top right) Geological map of the Tatau region modified from Wolfenden (1960), Liechti et al. (1960) and Heng (1992), as presented by Henning-Breitfeld et al. (2020). (Bottom) Interpreted stratigraphic relations of study locations $A, B$, and $C$ by the cited authors. The Belaga Formation appears as a metamorphic sequences of clastics, carbonates and volcanoclastics. A prominent Late Eocene/Base Oligocene Rajang unconformity separates the metamorphic Bawang Member from the above non-metamorphic Late Eocene-Early Oligocene shallow-marine clastics and carbonates.

Formation and various other local names) could be classified as a root of an orogen (Rajang-Crocker Fold Thrust Belt as annotated in Figure 1 inset map), which has been extruded and peneplained since the Early Miocene (in central coastal Sarawak), and again during Middle-Late Miocene (in northern coastal Sarawak). However, both its stratigraphy and tectonics still await a proper analysis and classification. Formation names and fieldwork stem mostly from the 1960's and data were gathered by Kirk (1957), Liechti et al. (1960),
Wolfenden (1960), Haile (1962), Adams (1965), and others during fieldwork campaigns. In the Tatau area, the Rajang Group forms a metamorphosed sequence of clastics, carbonates and volcanoclastics (Figure 4). Hutchison (2005) attempted to split the Rajang into a number of formation and members:

- The Belaga Formation (Bawang Member) consists of greywackes and distal turbidite laminites, magmatic rock and carbonate lenses. The member has since been redefined 


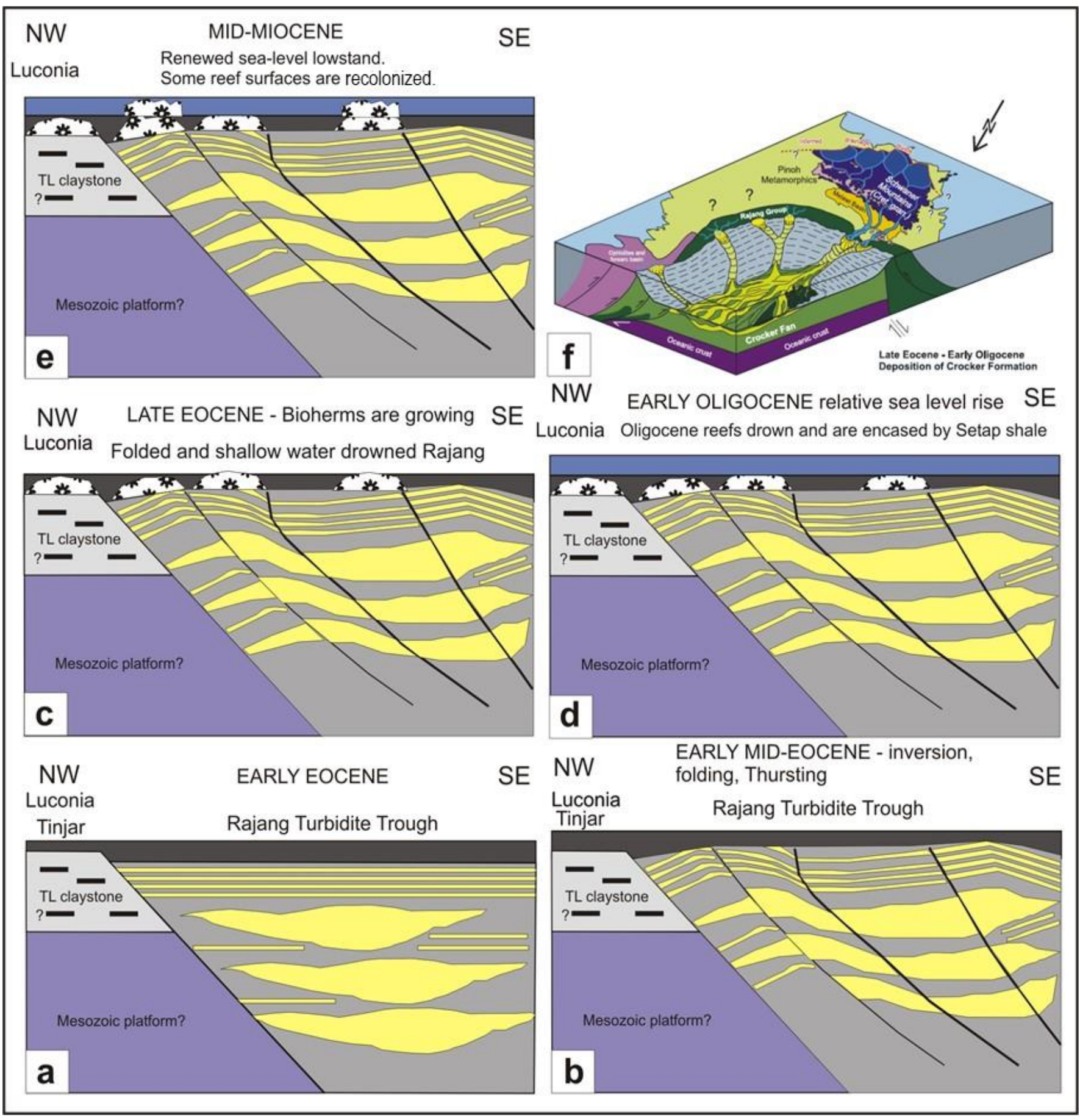

Figure 5a-e: Tectonic model of Rajang Group (from Jong et al, 2016); 2f. Depositional model for the Crocker Fan during the Late Eocene, showing the main source areas and transport paths (from van Hattum et al., 2013). Figures adapted from Nagarajan et al. (2020).

by Henning-Breitfeld (2019). The Arip volcanics and Piring intrusives yielded Eocene $\mathrm{U}-\mathrm{Pb}$ zircon values of 37-39+/- $1 \mathrm{Ma}$, with the carbonates Middle Eocene in age based on Foraminifera (Henning-Breitfeld, 2019).

- The Kelalan Formation, a turbidite sequence, with some subordinate limestone, tuffaceous limestone, slaty shale; the fauna is indicative for an age between Late Cretaceous to Eocene (Nagarajan et al., 2020).

- The phyllitic Mulu Formation is compared and correlated by Liechti et al. (1960) with the Belaga and Kelalan Formations, showing an age range between Paleocene and Lower Eocene. 
In detailed sedimentological studies, the turbidites and debrites in the Belaga Formation were interpreted as the deposits of basin floor submarine fans in the Cretaceous-Eocene at the northern margin of Sarawak (Zainol et al., 2007; Kuswandaru et al., 2018). A recent summary of the Rajang Group deposition is also offered by Nagarajan et al. (2020) (Figure 5), and the authors concluded, based on geochemical studies, that the mineral fingerprint underwent a mineralogical change indicating a shift from extensional to passive margin with some compressional characteristics. The youngest part of the Rajang Group is of Eocene Age, and it is overlain by Upper Eocene marine deposits, above the Rajang unconformity. We observe this in areas such as the Batu Gading quarry (see Hutchison 2005, p. 87 and Kessler \& Jong, 2017). The foraminifera-rich sequence above the unconformity should not be called Rajang, as this marine sequence may constitute an onlap onto the Rajang Basin.

\section{Nuang-1, offshore Mukah/Tatau (Half Graben Province)}

The Nuang-1 exploration well was drilled in early 2015 by PETRONAS on the edge of an offshore half graben into a condensed section of reportedly preCycle I (= Eocene to Oligocene) fractured basement metasediments, potentially the offshore extension of Belaga Formation (Figures 6 and 7; Jabbar et al., 2015). The sediments are expanding in thickness into the basin with the basal synrift half-graben fill, which is likely to contain Cycle I Eocene deposits (Figure 6). Arguably, Paleogene deposits should constitute a prominent part of the half grabens located offshore (Mukah/Tatau Formation in the Half Graben Province), and the Nuang-1 well represents the overlap of the Sibu and Miri zones.

The well terminated at $1234 \mathrm{~m}$ (mdbdf) and penetrated $122 \mathrm{~m}$ gross of oil-bearing fractured basement reservoir. Top basement was picked at $893 \mathrm{~m}$, and an oil sample of $39^{\circ}$ API gravity was recovered, which proved up a new play concept.

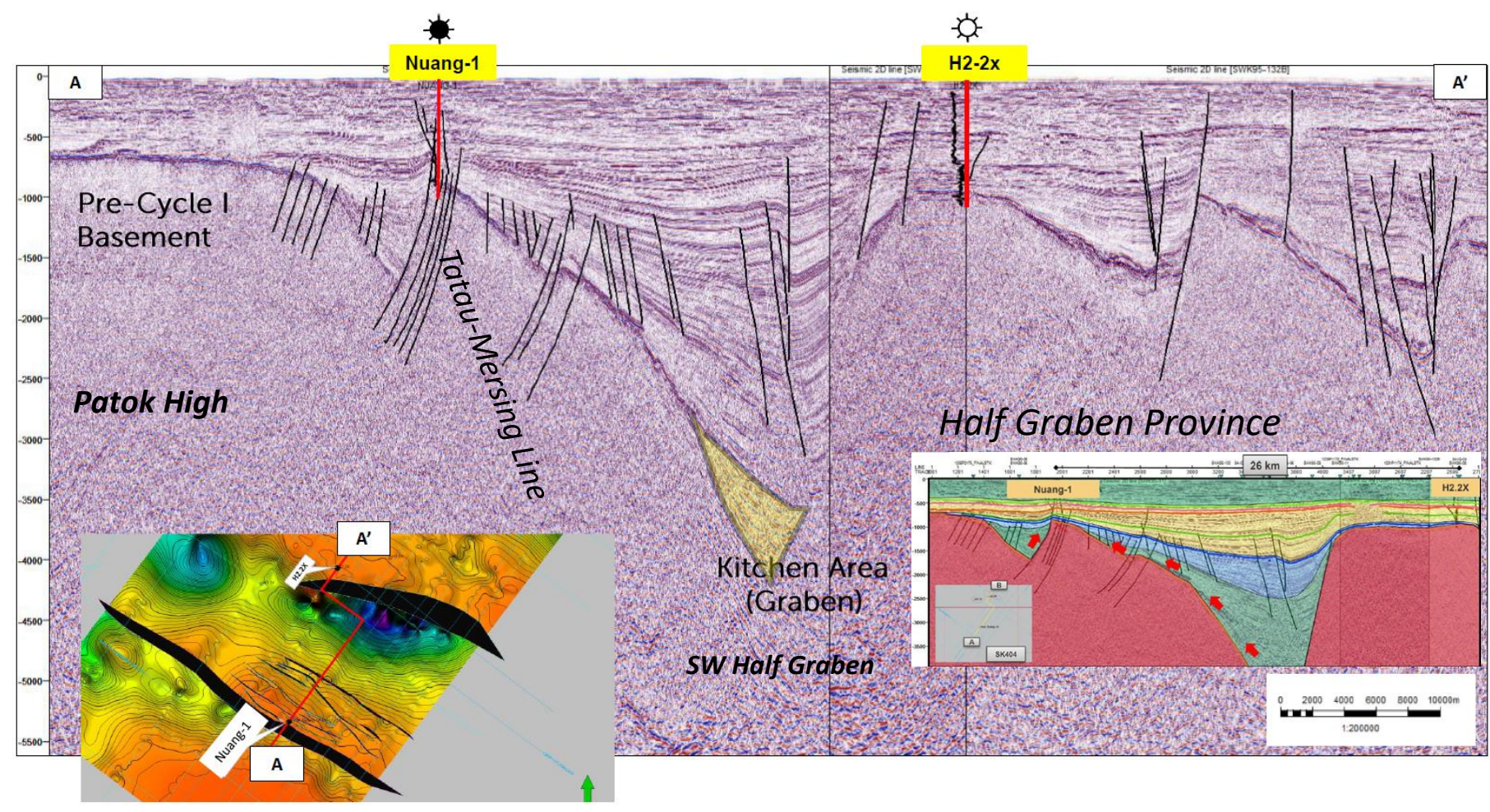

Figure 6: Regional seismic line illustrating structural setting and linking two exploration wells offshore Tatau located in Half Graben Province. The bottom-hole sequence in Nuang-1 was found to be of pre-Cycle I Early Paleocene age (see Figure 7) and is seen expanding towards the graben (yellow shaded area). 


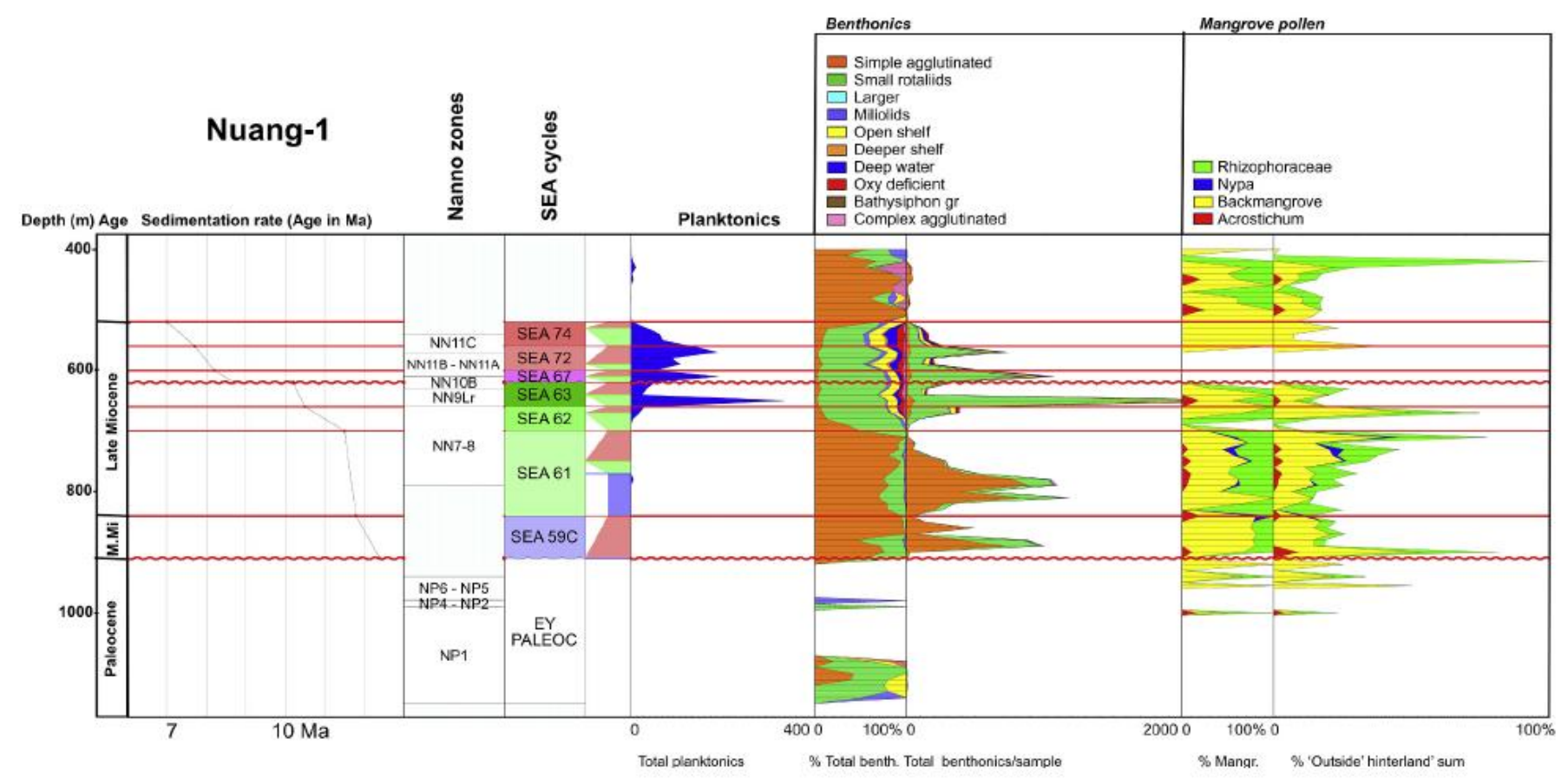

Figure 7: Nuang-1 well has a well-developed clastic Cycle IV interval, which is missing from most Sarawak wells. The Cycle IV sediments rest unconformably on Rajang Group sediments of Early Paleocene age. The first column shows total planktonic foraminifera per sample, followed by benthonic foraminifera, plotted as a percentage and number of specimens per slide. Mangrove pollen is plotted 'outside' the sum of "total hinterland pollen", and as a percentage itself. From Morley et al. (2020).

However, the significance of the well results, though not fully proven and only inferred from seismic observation indicate that the basal Cycle I could be in part Eocene in age and provide a potential data point for Paleogene sequences along Sarawak margin.

\section{4a. Engkabang/Karap Anticline (Miri Zone)}

The Engkabang wells were drilled over the Engkabang/Karap anticline in the inner Baram area of northern Sarawak, in the Miri Zone (Figure 1) (see Jong et al., 2016). Engkabang-1 was drilled by Shell in a 1959-1960 exploration campaign and penetrated late Middle Eocene to Oligocene carbonates above unmetamorphosed siliciclastics of unknown age. The well encountered a subeconomic gas accumulation in a $272 \mathrm{~m}$ section of massive, tightly cemented and dolomitized limestone, initially broadly assigned to a Late Eocene-Early Miocene age (Jong et al., 2016) (Figure 7). In 2013-2014, well Engkabang West-1 was drilled by JX Nippon and reached a Middle
Eocene sequence at TD (terminal depth) of ca. 4800 $\mathrm{m}$ mdbdf. This well penetrated a separate culmination of a mainly mudstone and wackestone sequence, but the mapped carbonate reservoirs were found to be tight (JX Nippon, 2014) (Figure 7). The anticline was a carbonate platform area, which was subjected to periods of compression, inversion and/or uplift (Jong et al., 2016) (Figure 5).

A biostratigraphic study was conducted on the new cutting samples from Engkabang West-1 by Core Laboratories (2014). Age-control and correlation to the Engkabang-1 section were facilitated by onsite foraminifera analysis ( $\mathrm{N}$ and $\mathrm{P}$ zones), followed by laboratory analysis of nannofossils (NP zones) (Figures 8). The top of the Younger Carbonate transitional facies (=top Melinau Formation; the first downhole occurrence of limestone intercalations) in both wells is coincident with the top of planktonic foraminifera zone P22, indicating an age of $c a .23 \mathrm{Ma}$, and the top of the Oligocene. The transition lithofacies ("Transition Zone") in both wells consists of silty claystone with 
Engkabang West-1

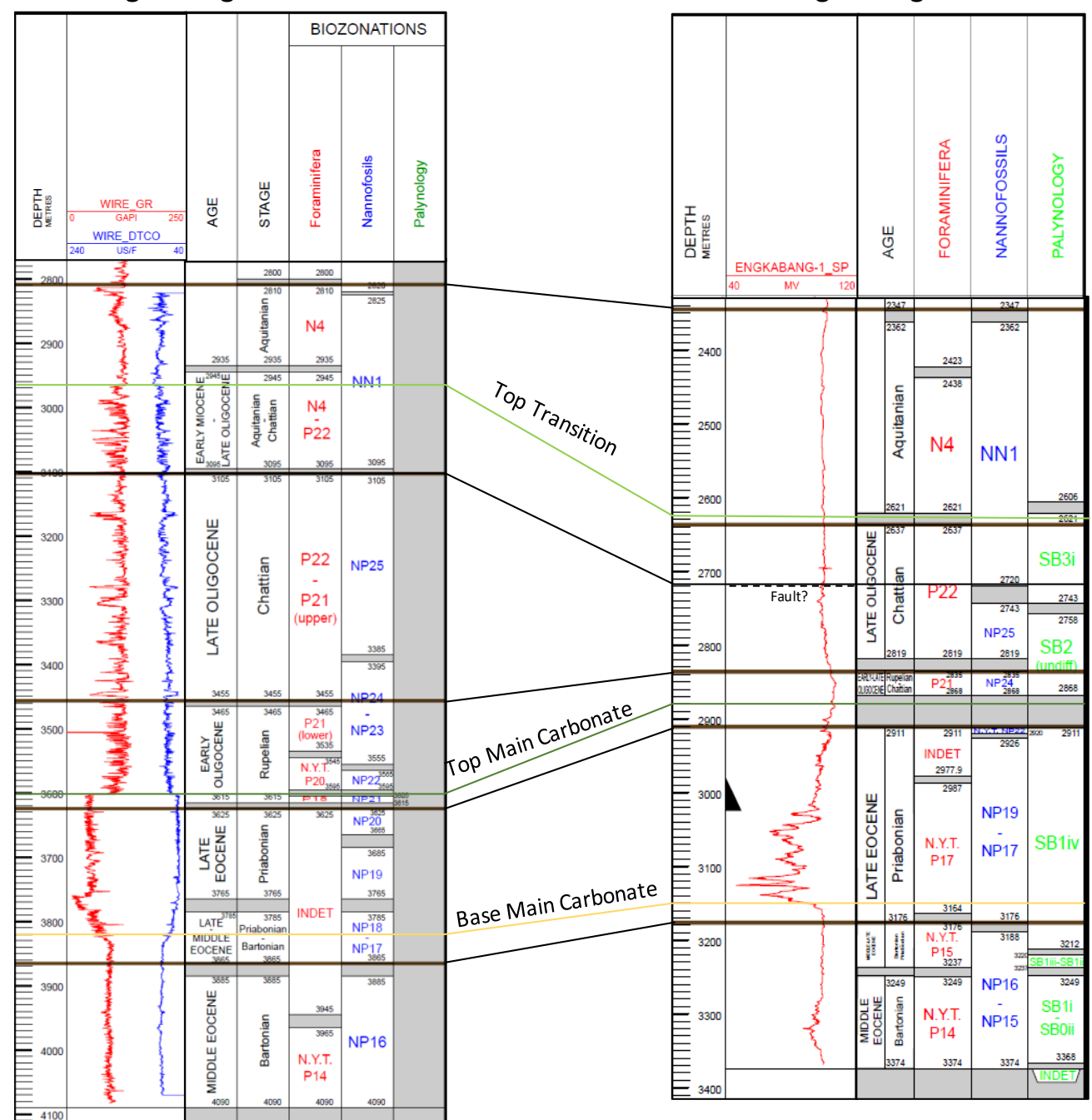

Figure 8: Engkabang West-1 to Engkabang-1 well correlation after JX Nippon (2014). The reanalyzed biostratigraphic results of Engkabang-1 indicated an age range for the carbonates of late Middle Eocene to Late Oligocene, representing some of the oldest carbonate rocks penetrated by any wells in the region Engkabang West-1 biostratigraphic investigation by Core Laboratories (2014) confirmed a similar-age range for the Engkabang-Karap carbonate section in the well (see Figure 1 for location; from Jong et al., 2016).

intercalations of sandstone and limestone, and ranges in age from Early to Late Oligocene in both wells. In Engkabang West-1 the transitional lithofacies is approximately $350 \mathrm{~m}$ (true vertical thickness) thicker than in Engkabang-1, where the interpreted paleoenvironments are similar, probably due to the presence of depositional hiatuses at the Engkabang-1 location, which might have been in slightly shallower environments of deposition than Engkabang West-1. In Engkabang West-1 the age of the main part of the Melinau Formation carbonate is Late Eocene, based on biostratigraphic evidence, which is consistent with the same main carbonate in Engkabang-1. The claystone interval below the carbonate ("Engkabang Marl") is of Middle Eocene age, also based on biostratigraphic evidence in both wells.

Seismic sections of the Karap/Engkabang anticline, calibrated with biostratigraphic data from the wells indicate the presence of a number of key stratal events related to regional unconformities and hiatuses (Figure 9). Furthermore, a biofacies study indicated that the basal sedimentary section of Engkabang wells represented some of the oldest Late Eocene Cycle I carbonate rocks penetrated by any wells in the region. It was similar in age to that of the Melinau 
Limestone outcrop section of NW Sarawak, previously investigated by Adams (1965), and restudied by Lunt (2014). If the interpretation of the TD section (i.e., Eocene Cycle I) is correct, it would suggest that the molasse of Sarawak Foreland Basin is located in an entirely different tectonic stratigraphic summary is also given in Hutchison (2005, p.87) (Figure 10). According to these authors, the lower carbonate body is of Upper Eocene age, whereas the limestone above the second unconformity was dated as Lower Miocene.

A review by P. Lunt (pers. comm.) suggests,

\begin{tabular}{|c|c|c|c|c|c|}
\hline Biofacies Unit & Engkabang West-1 & Engkabang -1 & Series name & Stage Name & $\begin{array}{l}\text { Composite } \\
\text { zonal ranges }\end{array}$ \\
\hline EJ & Present & Present & Early Miocene & $\begin{array}{l}\text { Burdigalian } \\
\text { - } \\
\text { Aquitanian }\end{array}$ & $\begin{array}{l}\text { NN2 } \\
\text { N5 }\end{array}$ \\
\hline El & Present & Present & Early Miocene & Aquitanian & $\begin{array}{l}\text { NN1 } \\
\text { N4 }\end{array}$ \\
\hline \multicolumn{6}{|c|}{ Sequence Boundary 23.0 Ma (boundary between Miocene and Oligocene) } \\
\hline EH & Present & Present & Late Oligocene & Chattian & $\begin{array}{l}\text { NP25 } \\
\text { P22 }\end{array}$ \\
\hline EG & Present & $\begin{array}{c}\text { Not present (approx. } 3 \text { my } \\
\text { erosion or hiatus?) }\end{array}$ & Late Oligocene & Rupelian & $\begin{array}{c}\text { NP25 } \\
- \\
\text { NP24 } \\
\text { P22 } \\
- \\
\text { UpperP21 }\end{array}$ \\
\hline EF & Present & Present & Early Oligocene & Rupelian & $\begin{array}{c}\text { P21 (Lower) NP24 } \\
- \\
\text { NP23 }\end{array}$ \\
\hline
\end{tabular}

Sequence Boundary 33.7 Ma (boundary between Oligocene and Eocene) Possibly up to 2 my "missing" in Engkabang-1

\begin{tabular}{|c|c|c|c|c|c|c|}
\hline $\begin{array}{c}\text { EE (Main } \\
\text { carbonate) }\end{array}$ & Present & Present & Late Eocene & Priabonian & NP21 \\
NP19
\end{tabular}

Figure 9: Established Palaeogene biofacies of Engkabang wells. The Eocene biofacies units EJ to EC denote the local "Engkabang" biofacies. The absence of biofacies units EG and ED in Engkabang-1 is likely due to erosion and/or depositional hiatus, with three significant erosional events were observed at 37.1 Ma (approx. Rajang Unconformity), 33.7 Ma, and 23.0 Ma (from Jong et al., 2016).

block (with no Rajang Group present), underlain by a different and unknown basal sedimentary section.

\section{4b. Batu Gading (Miri Zone)}

Foraminifera from the Batu Gading outcrops were studied by Liechti et al. (1960), Adams and Haak (1962) and later by Ngau (1989). A very good however, that the upper part of the limestone sequence is of Late Oligocene age and that the Lower Miocene may be missing. The upper limestone body (above the second unconformity) in the studied location appears to be far more prominent compared to what was described in the literature, and only the upper carbonate body could be studied and logged in detail. The sequence 
starts with foraminifera wackestones/packstones and indicates a moderate energy environment of fully marine conditions. The central sequence is formed by poorly exposed patch reefs surrounded by packstone/grainstone facies. We see here a high-energy environment with good sorting and marine-phreatic cementation. The uppermost, platy limestone sequence may, subject to confirmation by microfacies analysis, represent an outer shelf - neritic carbonate sequence. In summary, the age and lithology context should be further investigated.

The only angular unconformity between carbonate bodies lies near the base of the carbonate column below the larger foraminifera (nummulite) horizon
- this we refer to as the Rajang Unconformity (Figure 10). However, a disconformity/ unconformity between the massive limestone and the overlying slaty limestones could not be located.

\section{Batu Niah Subis Limestone (Miri Zone)}

The Subis build-up is one of the Cycles I-II carbonate outcrops exposed in coastal Sarawak, with an exposed thickness of $390 \mathrm{~m}$ (Figures 1 and 11). It is a massive, prominent cliff-forming limestone hill and hosts the famous Batu Niah caves at the northern flank of the build-up. The build-up is composed of massive and branching corals, coralline red algae, benthic foraminifera, bivalves, gastropods, echinoids, and occasionally bryozoans and sponges, which provide an

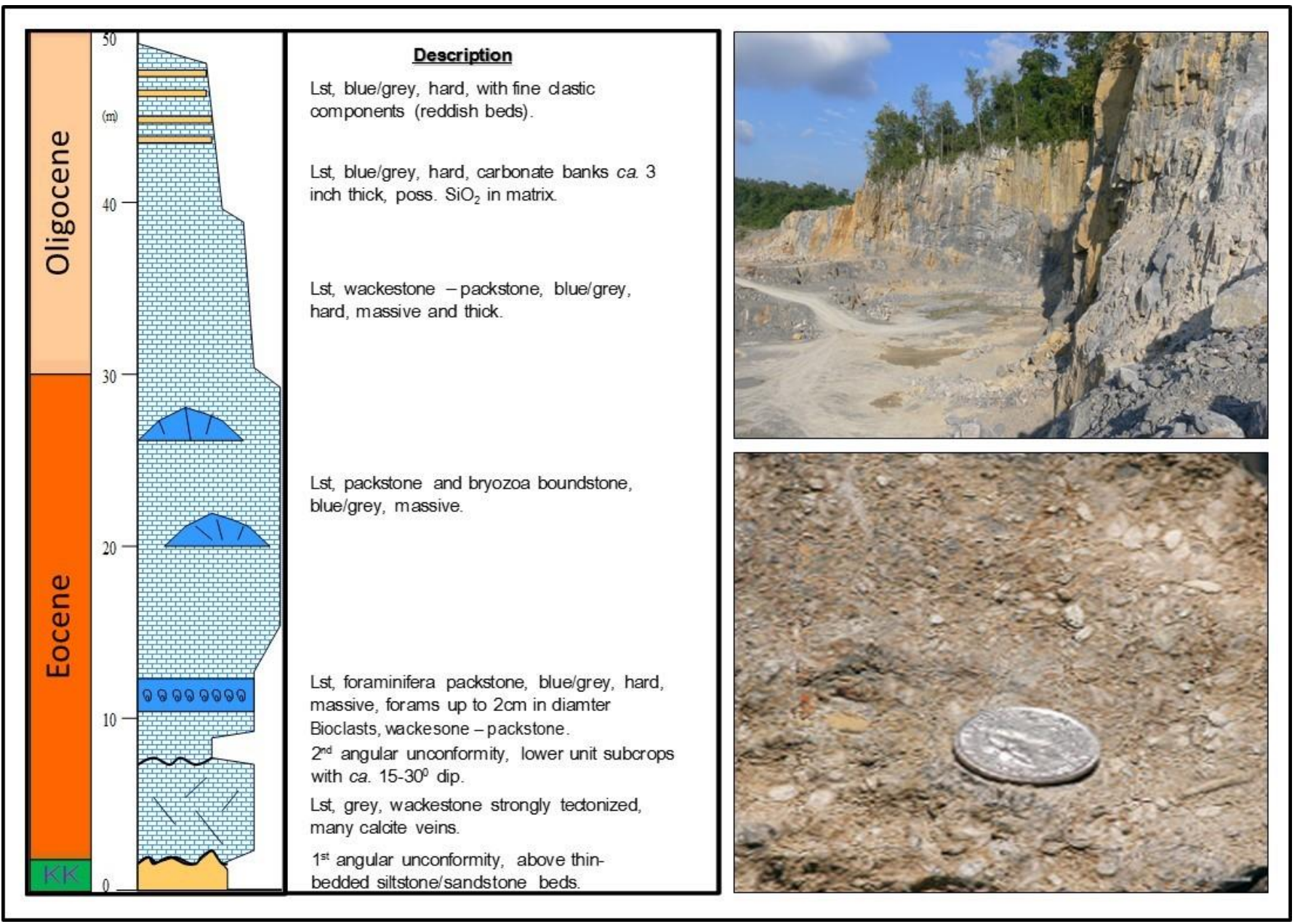

Figure 10: Vertical profile of Batu Gading limestones (Hollystone quarry, after Kessler, 2013). Top right: The Hollystone quarry is located in the vicinity of the Baram-Luconia/Tinjar tectonic segments (see Figure 1 for location), imbricated between older Kelalan metamorphics. However, there is no indication that the Batu Gading limestone has undergone metamorphism. Bottom right: Laterally continuous band of benthonic foraminiferal packstones with clay component of a ramp facies ca. $2 m$ above the Rajang Unconformity. From Kessler and Jong (2017). 


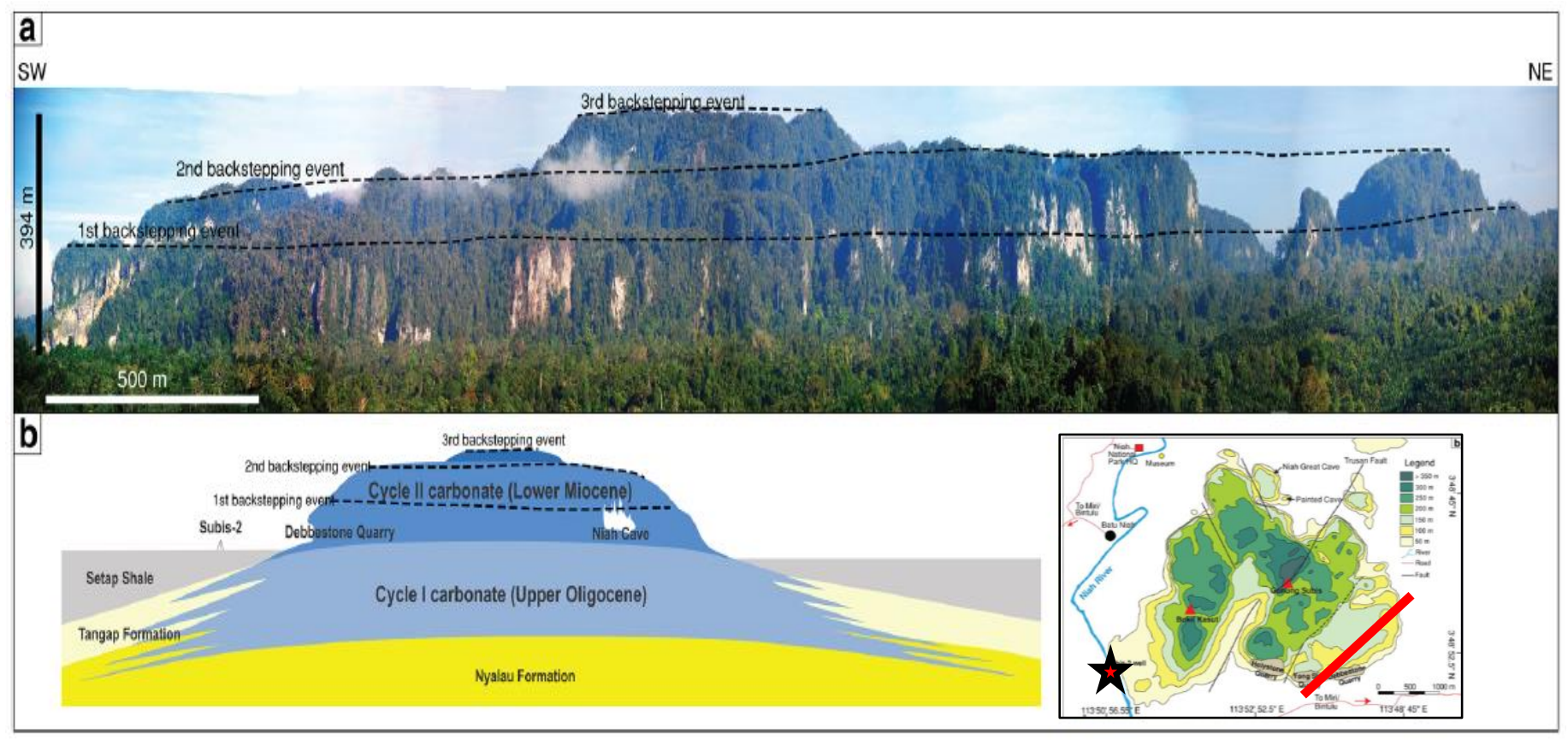

Figure 11: (a) The architecture of the Subis build-up. A view taken from the telecommunication tower at the eastern side, opposite to the Subis build-up. (b) The build-up is surrounded by Setap Shale, interfingering with the Tangap and Nyalau formations, as shown in the schematic cross-section diagram. Inset shows topographic map of the Subis buildup with Subis-2 well location annotated by the red star symbol. Modified after Saw et al. (2019).

opportunity to document the composition and architecture of rim and talus deposits in an isolated build-up as an analogue for similar gasbearing structures located offshore Central Luconia (Saw et al., 2019).

The stratigraphic succession of the Subis build-up is named the Subis Limestone (Liechti et al., 1960; Hazebroek et al., 2000; Dedeche, 2012). It was developed on paleo-high in clear, shallow seawater with normal salinity (Hazebroek et al., 2000; Hutchison, 2005; Saw et al., 2019), and represents a carbonate build-up in a siliciclastic dominated section. The Subis Limestone is referred to as a member of Tangap Formation by Burr and Crews (1950) and Liechti et al. (1960), which is itself laterally equivalent to part of the widely distributed, but less calcareous Setap Shale, a thick clayey section that grades to the southwest into the sandy Nyalau Formation (Liechti et al., 1960; Haile, 1962) (Figures 11 and 12).

In southernmost Sabah, the Setap Shale has been split into an older unit called the Temburong Formation and the younger Setap Shale by
Brondijk (1962), with a major unconformable boundary, dated as being in the basal part of the Letter Stage Te5 (Liechti et al., 1960), close to the Oligo-Miocene boundary. As noted by Lunt and Madon (2017), this Te4 to T5 boundary unconformity represents the Cycle I to Cycle II boundary. Previous studies done in the Subis area (Haile, 1962; Roohi, 1994; Wilson et al., 2013; Lunt and Madon, 2017) have found the main body of the Subis Limestone to contain Te5 (basal Miocene) foraminifera, but the mixed series of thin limestones and claystones in the nearby Subis-2 well was dated to be $\mathrm{Te} 4$ (Late Oligocene) in age. The well was drilled between 1951 and 1953 on the southwestern flank of the Subis Limestone and penetrated both the cliff and deeper clastics down to more than $10000 \mathrm{ft}$ (3028m; Kessler and Jong, 2017). It is noted that the lower sequence of the Subis Limestone in Batu Niah is Middle Oligocene in age. The reef complex overlies marine claystone and marlstone of Eocene (?) to Oligocene age (Dedeche et al., 2013; Kessler and Jong, 2017) (Figure 12). 


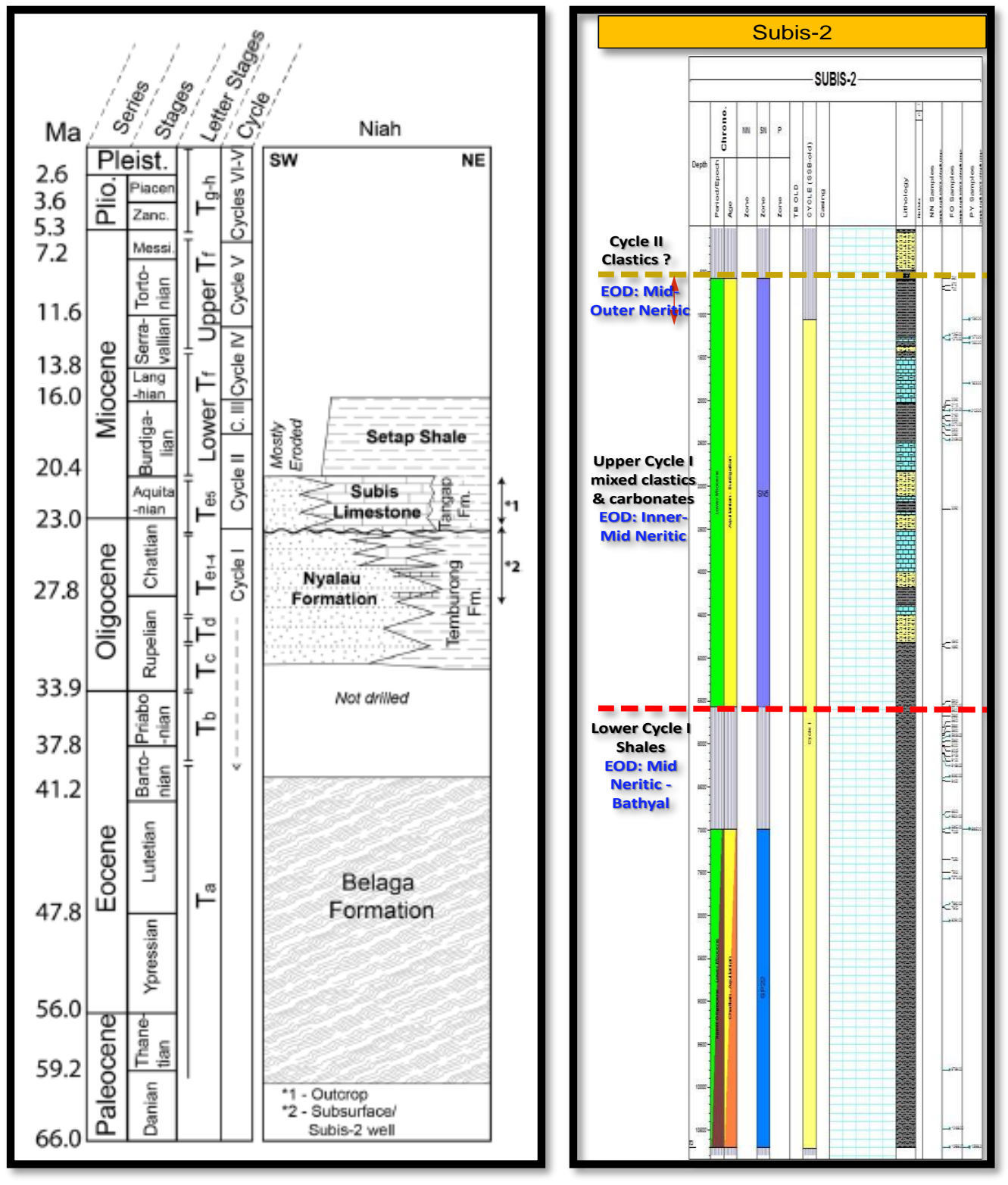

Figure 12:

(A)

Chronostratigraphic context of the Subis Limestone, Batu Niah. The age of the Subis Limestone is Late Oligocene to Early Miocene, equivalent to Cycles I-II carbonates in Central Luconia (after Liechti et al., 1960; Hutchison, 2005; Wilson et al., 2013; Lunt and Madon, 2017). From Saw et al. (2019). (B) Well Subis-2 drilled through the Batu Niah reef complex of Early Miocene age and penetrated until TD a sequence of neritic Oligocene clay and marlstone. If the bottom-hole section contains clastic Eocene-age rocks, and of which formation, remains an unresolved question, given the 1953 well data remain inconclusive. The older exploration wells in the area however refer to the clay-prone Paleogene section as Belaga Formation as shown in (A). It is unclear whether this was expressed in a stratigraphic or tectonic sense. Modified after Kessler and Jong, 2017.

\section{UNCONFORMITIES AND CORRELATIONS}

Following Hutchison (2005), there are two spectacular unconformities, the Rajang Unconformity and the near-Top Eocene/Base Oligocene Unconformity along the Sarawak margin:

- In the Tatau area (Figure 4), the intra-Late Eocene Rajang angular unconformity separates the underlying and strongly deformed phyllitic Belaga Formation from the overlying non-metamorphic Rangsi Conglomerate of the Tatau Formation near Tatau (Figure 4).
- The same unconformity separates the metamorphosed Kelalan Formation from the overlying Melinau Limestone in the Batu Gading outcrop (Figure 10).

- At Engkabang/Karap Anticline the Rajang Unconformity is identified in the two wells as a prominent hiatus of approx. 2 Myr duration in the wells (Figure 9), represented by the missing biozone NP zone 18.

- A near-Top Eocene/Base Oligocene unconformity is seen at both the Batu Gading and the Engkabang areas. In the Engkabang 
wells, biozone NP zone 22 is missing which implies again a hiatus of some 2 Myr.

- The correlation with well Nuang-1 appears to be more challenging. There is a very marked unconformity at ca. $920 \mathrm{~m}$ which separates Middle Miocene rocks from underlying Eocene (?) Rajang Group rocks. Therefore, the observed unconformity could be an amalgamation of the Rajang Unconformity, the Base Oligocene Unconformity and a MidMiocene unconformity event. Most likely, however, we are seeing non-deposition during the Oligocene and Early Miocene, while sedimentation may have continued during Late Eocene, Oligocene, and Early Miocene times downflank of the well in the deep half grabens. This is also corroborated by the section as shown in Figure 6.

- The most difficult correlation presents itself in the Kuching Zone, given there are no rocks younger than Eocene. Therefore, in speculative terms, the current landscape may be coeval with either Rajang Unconformity, Base Oligocene unconformity, or both. Reasons for this remains speculative, but hydrocarbon maturity analysis by Johannson (1999) suggests significant erosion of younger Tertiary rocks.

\section{DISCUSSION}

From a comparison between the Engkabang/Karap area and time-coeval strata in Rajang Group outcrops of the Tatau area, it is quite clear that the investigated areas onshore Sarawak are fundamentally different from each other, and likely belonging to adjacent and partly coeval, yet distinct basins, at least until the early Late Eocene.
Existing field-geology data on the Rajang Group suggest a Lower (?) Cretaceous-Mid/Late Eocene depositional fill history in a relatively narrow graben, which possibly opened zipper-style from East to West, leading to sea floor spreading, and during the mentioned time span, accumulated $4000 \mathrm{~m}$ of sediments, starting with deep marine turbidite to shallow marine sediments, including carbonates. Arguably, older pre-Eocene deposits correspond to deepwater turbidite channel and fan complexes (van Hattum et al., 2013; Galin et al., 2017), whilst the uppermost Rajang (Bawang member in Tatau Formation) also contains shallow marine carbonate rocks. Due to a shortening of crust, the sediments of the Rajang-Crocker graben were compressed, metamorphosed and rearranged by complex, thrust, strike-slip and nappe tectonism.

If the age determinations are correct, it would leave very little (intra-Eocene) time for a series of sedimentary tectonic processes:

- A rapid shallowing-up in the Rajang Group, from deep-marine clastics to shallow-marine carbonate clastics and volcanic rocks. Some minor spurious oyster patch reefs in the Long Lama area indicate a very shallow marine setting as the Rajang depocenter has filled up;

- Followed by intense folding and thrusting;

- Regional metamorphism of a highpressure/low temperature type affecting most of the area;

- Uplift and exhumation of the sequence. Studies by Kessler and Jong (2015a \& b), carried out in the context of an ongoing exhumation upheaval suggest erosion of some $6000 \mathrm{~m}$ of Rajang sediments, an estimate based on mass-balance calculations and metamorphic indicators. These data are 


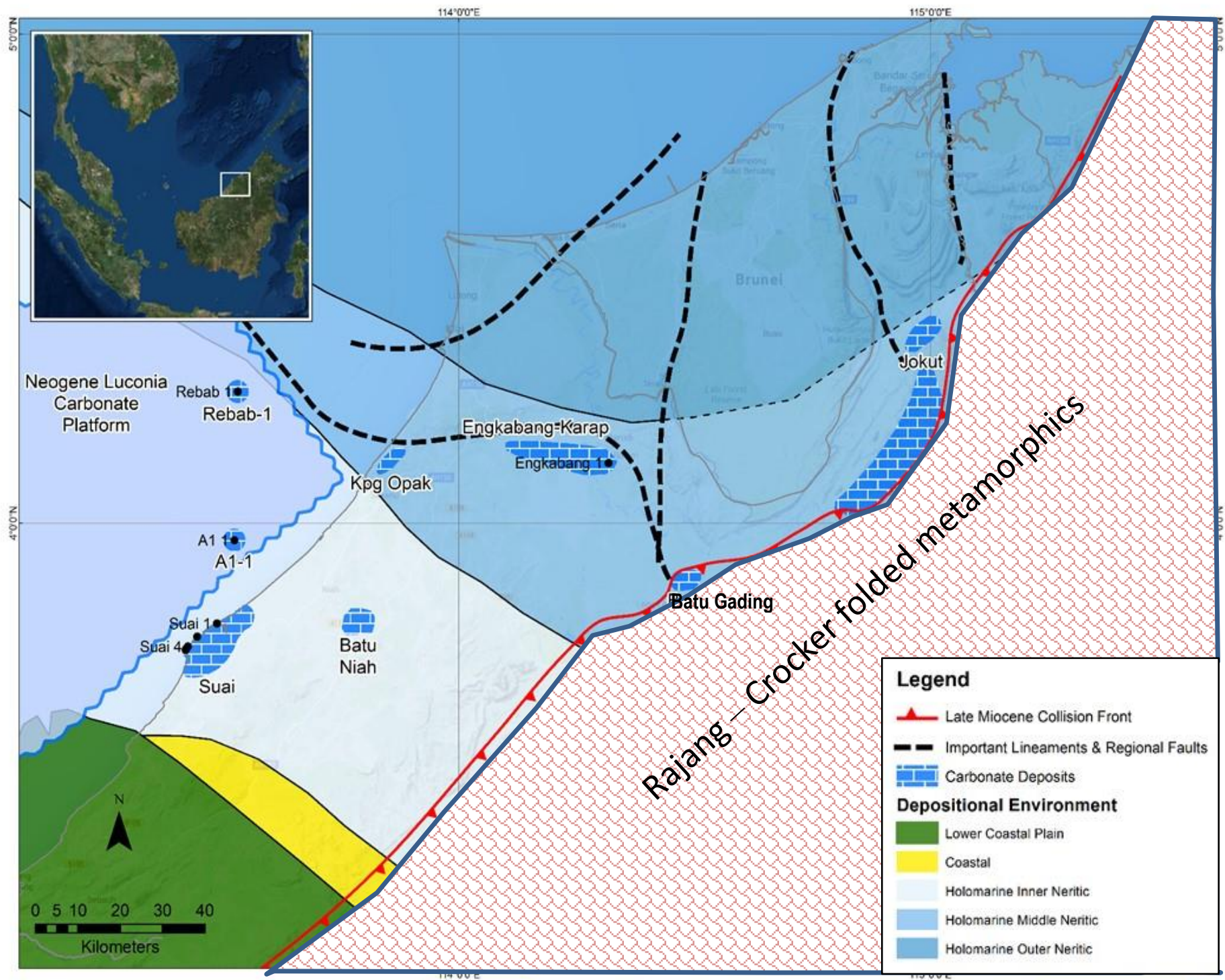

Figure 13: Regional palaeo-environment map of northern coastal zone of Borneo with carbonate distributions discussed Engkabang, Batu Gading and Batu Niah illustrating the variation in depositional environments at Cycle I time (Early Miocene to Late Oligocene; 37 - 23 Ma). Modified after Abdullah et al. (2015) and Jong et al. (2016).

comparable to uplift estimates in Sabah by Cottam et al (2013), in particular of the Mt. Kinabalu Massive. Evidence was given from thermochronology indicating that parts of Borneo saw unusual uplift and exhumation rates;

- Followed by marine wave erosion, when the near-coastal Rajang Group was peneplained;

- Followed by shallow marine carbonate deposition; and

- Renewed deepening and deposition of neritic carbonates and clastics.
In the Miri Zone, and outside of the core Rajang Group areas, we see neritic to shelfal deposits of Late Eocene to Oligocene age (Figure 13). Shelfal to inner neritic sediments are exposed in the Batu Gading quarry, and the Batu Niah reef complex. The Batu Gading quarry (see also Hutchison 2005; Kessler and Jong, 2017) points to intra-Eocene erosion, overlain by shallow marine Eocene carbonates leading to a sequence of neritic carbonate and fine- Oligocene and Miocene clastics. The Engkabang/Karap Anticline wells however show a sedimentary (non-metamorphic) sequence formed by Eocene Cycle I deep shelfal 
carbonates and shales, followed by neritic shale (Jong et al., 2016; Kessler and Jong, 2016 \& 2017). forearc basin derived from the magmatic arc at the Sundaland-Pacific margin. This was underpinned by earlier field work by Tongkul

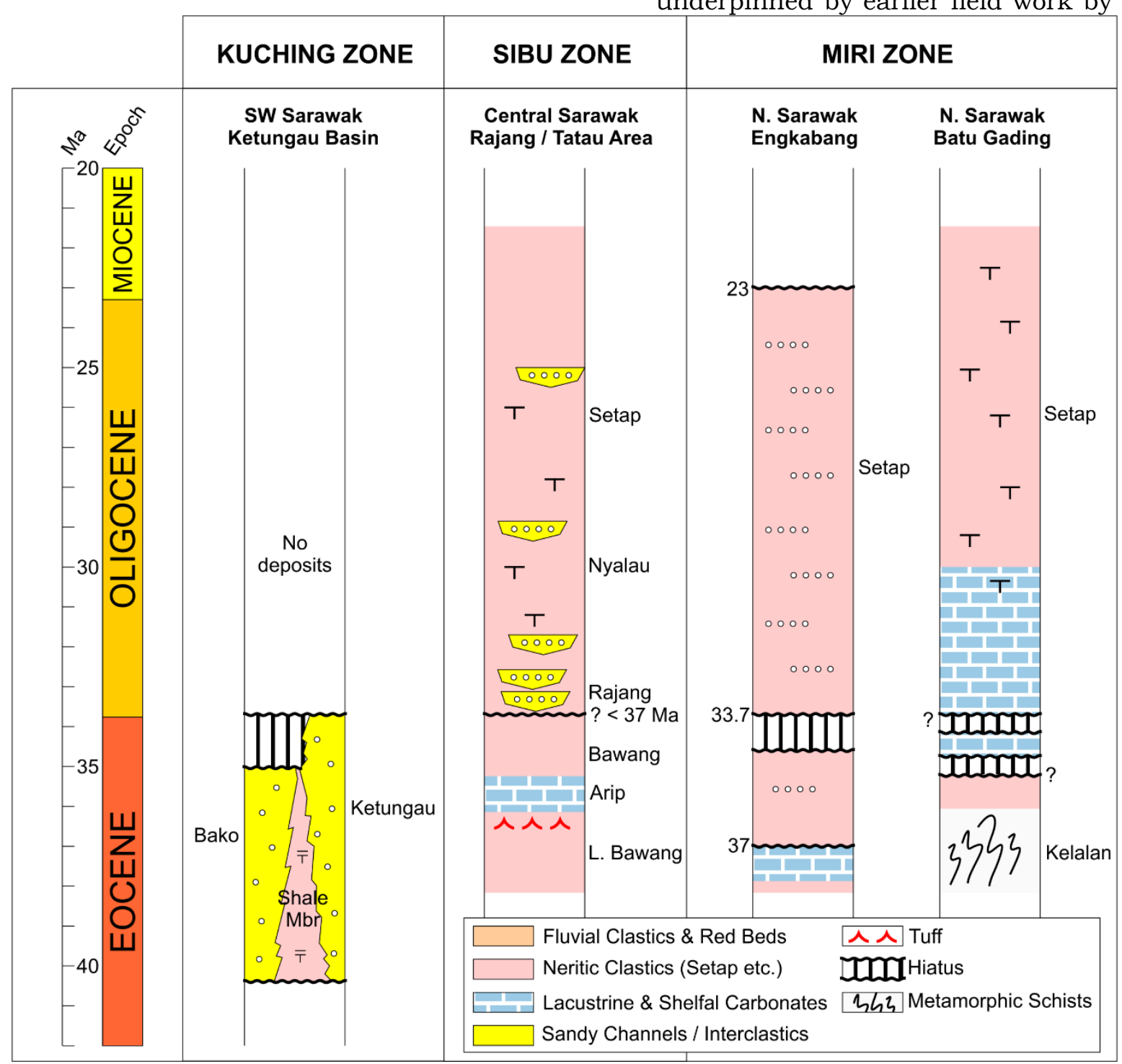

Figure 14: A comparison of Paleogene sequences along the Sarawak margin - southwest Kuching Zone, central Sarawak Sibu Zone Rajang Group outcrops in Tatau area, and northern Sarawak Miri Zone Engkabang/Karap and Batu Gading. The Base Oligocene unconformity recorded in the Engkabang wells is co-eval to the Rajang Unconformity of central Sarawak. Noted also are the differences in the depositional environments of the investigated wells and outcrops in the study areas.

Further southwest, in the Kuching Zone area, we see fluvial sandstone deposits adjacent to the Schwaner Mountains, interpreted to be the original source of all clastic sediments in northern Borneo.

Summarizing the above, we can distinguish three radically different depositional settings in the Paleogene of Sarawak:

1. The fluvial clastics of the Kayan and Plateau sandstones. According to Breitfeld et al. (2018), these sediments were deposited in a
(1997). West Sarawak and NW Kalimantan are underlain by continental crust that was already part of Sundaland at that time.

2. The exhumed Rajang Group deposits conclude with clastics, shallow marine limestone, and magmatites in the Early Late Eocene; arguably the Rajang/Crocker formed in a basin distinct from the neighboring early SCS.

3. The rim of the SCS in the Miri zone, Central Luconia to the Tinjar Block, was formed by 
Late Eocene to Oligocene slope sediments with carbonate reefs.

With comparison from the Eocene or older deposits of the Penyu and Malay basins, a review of the paleogeography of the SCS region on the eastern margin of Sundaland is needed to better refine the Eocene-Oligocene paleogeographic evolution of the south-western SCS, and the tectonic relationship between the above-mentioned areas of offshore East coast Peninsular Malaysia and the Sarawak margin. Figure 14 provides a summary of the comparison of Paleogene sequences along the Sarawak margin, where Top N, a regionally significant unconformity in the Penyu and Malay basins, is coeval to the Base Oligocene Unconformity recorded in the Engkabang wells and the Rajang Unconformity of central Sarawak. Noted also are the differences in the depositional environments of the investigated wells and outcrops in the study areas. Our research effort will continue with this integration study.

\section{CONCLUSIONS}

The Sarawak margin located in the southern SCS area contains three different depositional settings with Paleogene rocks.

The uppermost Cretaceous to Lower Eocene Kayan and Plateau sandstones of the Kuching Zone represent a fluvial depositional setting. In contrast, the Sibu Zone, in the Rajang Fold-Thrust Belt is composed of Late Cretaceous to Late Eocene clastics, shallowing upwards from deep marine sediments to a shallow marine setting, which were later metamorphosed. Outcrops and deep wells that penetrated Eocene sequences in the Miri Zone indicate shelfal and neritic clastics and carbonates, and also clay-dominated neritic rocks.
There are two major unconformities in the Paleogene of Sarawak: The Eocene Rajang Unconformity of approximatively $37 \mathrm{Ma}$, and a near-Top Eocene (= Base Oligocene) unconformity of 33.7 Ma. Interestingly, both unconformities are present in the Rajang Group, as well as in the coastal basin. The presence of Eocene strata along the margins of Sundaland is likely associated with an early phase of extensional tectonism, which was similarly observed in the Penyu and Malay basins, offshore Peninsular Malaysia, and is probably related to the onset of rifting of the South China Sea continental crust.

The implication of this is that extensional movements in the south-western SCS started much earlier than the Oligocene, as previously thought. The opening of Eocene half-grabens and Eocene to Early Oligocene filling depocentres in the coastal waters of Sarawak and elsewhere might also point towards the possibility of a new petroleum play.

\section{ACKNOWLEDGEMENTS}

This study is a continuation of research on the Paleogene deposits of the south-western South China Sea, which we started with the review of the Paleogene sedimentary record of the Penyu and Malay basins (Kessler et al., 2020), and extended it into the Sarawak margin, as summarized in this paper. The research has benefited greatly from the discussion and published work of past and present authors who contributed to the ideas presented in this paper, and to whom we are indebted. However, any mistakes or shortcomings remain the responsibility of the authors. Our gratitude is also extended to our reviewers for offering constructive comments, which help to improve the quality of this paper. 


\section{REFERENCES CITED}

Abdullah, N.S., Sumery, N.F.M., Jirin, S., Sirodj, H.E. and Mohamad, H., 2015. Enhancement of regional EOD of the Sarawak basin using multiple geological data calibration. Asia Petroleum Geoscience Conference \& Exhibition (APGCE 2015), Kuala Lumpur, Program Book and Extended Abstracts, p. 349-353.

Adams, C.G., 1965. The foraminifera and stratigraphy of the Melinau Formation, Sarawak, and its importance in Tertiary correlation. Quart. J. Geol. Soc. London, 121, p. 283-338.

Adams, C.G. and Haak, R., 1962. The stratigraphical succession in the Batu Gading area, Middle Baram, North Sarawak. In: N.S. Haile, The geology and mineral resources of the Suai- Baram Area, North Sarawak. British Borneo Geol. Survey Mem. 13, p. 141-150.

Adepehin, E.J., Aziz Ali, C. and Dali, M.S., 2019. An overview of 20 years' hydrocarbon exploration studies and findings in the Late Cretaceous-toTertiary onshore Central Sarawak, NW Borneo: 1997-2017 in retrospect. Journal of Petroleum Exploration and Production Technology, 9, p. 1593-1614.

Banda, R.M, 1999. The geology and planktic foraminiferal biostratigraphy of the Northwest Borneo basin, Sarawak, Malaysia. Ph.D. Thesis, University of Tsukuba, Japan, p. 1-145.

Breitfeld, H.T., Hall, R., Galin, T. and BouDagher-Fadel, M.K., 2018. Unravelling the stratigraphy and sedimentation history of the uppermost Cretaceous to Eocene sediments of the Kuching zone in West Sarawak (Malaysia), Borneo: Journal of Asian Earth Sciences, 160, p. 200-223.

Brondijk, J.F., 1962. A reclassification of a part of the Setap Shale Formation as the Temburong
Formation. British Borneo Geological Survey Annual Report, p. 56-60.

Burr, I.L and Crews, W.E., 1950. Report on the Subis-Bintulu area, GR526.

Burton, D. and Wood, L.J., 2010. Seismic geomorphology and tectonostratigraphic fill of half grabens, West Natuna Basin, Indonesia. AAPG Bulletin, 94, 11, p. 1695-1712.

Core Laboratories, 2014. Engkabang West-1, Block SK333, Onshore Sarawak, Malaysia. Biostratigraphy and paleoenvironments of the interval 120m-4090m. Unpublished Report.

Cottam, M., Hall, R., Sperber, C., Kohn, B. P., Forster, M. A. and Batt, G. E., 2013. Neogene rock uplift and erosion in Northern Borneo: evidence from the Kinabalu granite, Mount Kinabalu, Journal of the Geological Society. 170, 5, p. 805-816

Dedeche, A., 2012. Growth history and facies evolution of the Miocene carbonate limestone of Gunung Subis, onshore Sarawak. MSc thesis, Universiti Teknologi PETRONAS, Kuala Lumpur.

Dedeche, A., Pierson, B. and Hunter, A., 2013. Growth history and facies evolution of the Subis limestone - A carbonate platform exposed onshore Borneo Island, Malaysia. In: Proc. $75^{\text {th }}$ EAGE Conference \& Exhibition incorporating SPE EUROPEC: Carbonate Depositional Environments \& Diagenesis, June 10-13 th 2013, London, p. 5557.

Galin, T., Breitfeld, H., Hall, R. and Sevastjanova, I., 2017. Provenance of the Cretaceous-Eocene Rajang Group submarine fan, Sarawak, Malaysia from light and heavy mineral assemblages and U$\mathrm{Pb}$ zircon geochronology. Gondwana Research, 51, 209-233. 
Geological Survey of Malaysia, 1995. Annual Report 1995. Geological Survey Department, Ministry of Primary Industries, Kuala Lumpur.

Haile, N.S, 1962. The geology and mineral resources of the Suai-Baram area, north Sarawak., British Borneo Geol. Survey Memoir 13, 176p.

Haile, N.S., 1969. Geosynclinal theory and the organizational pattern of the Northwest Borneo Geosyncline. Quarterly Journal of the Geological Society of London, 124, p. 171-194.

Haile, N.S., 1974. Borneo. In: Spencer, A. M., (ed.), Mesozoic-Cenozoic Orogenic Belts: Data for Orogenic Studies, Geological Society London, Special Publication 4, London, p. 333-347.

Haile, N.S., Lam, S.K. and Banda, R.M., 1994. Relationship between gabbro and pillow lavas in the Lupar Formation, West Sarawak: Implications for interpretation of the Lubok Antu Melange and the Lupar Line. Bulletin of the Geological Society of Malaysia, 36, p. 1-9.

Hazebroek, H.P., Abang Moshidi, A.K., Wong, K.M. and Chung, R.C.K., 2000. National parks of Sarawak. Natural History Publications (Borneo), Malaysia, p. 199-210.

Heng, Y.E., 1992. Geological Map of Sarawak, 1:500,000. Geological Survey of Malaysia.

Hennig-Breitfeld, J., Breitfeld, H.T., Hall, R., BouDagher-Fadel, M. and Thirlwall, M., 2019. A new upper Paleogene to Neogene stratigraphy for Sarawak and Labuan in northwestern Borneo: Paleogeography of the eastern Sundaland margin. Earth-Science Reviews, 190, p. 1-32.

Hennig-Breitfeld, J., Breitfeld, H.T., Hall, R. and BouDagher-Fadel, M., 2020. Reply to Discussion: Hennig-Breitfeld, J., Breitfeld, H.T., Hall, R., BouDagher-Fadel, M. and Thirlwall., M., 2019. A new upper Paleogene to Neogene stratigraphy for
Sarawak and Labuan in northwestern Borneo: Paleogeography of the eastern Sundaland margin. Earth-Science Reviews, 190, 1-32. Earth-Science Reviews, 202 , https://doi.org/10.1016/j.earscirev.2019.103066

Hutchison, C.S., 1989. Geological Evolution of South-East Asia. Oxford monographs on Geology and Geophysics, 13, Clarendon Press, Oxford, 368p.

Hutchison, C.S., 1996. The "Rajang accretionary prism" and "Lupar Line" problem of Borneo. In: Hall, R. and Blundell, D.J. (eds.), Tectonic Evolution of Southeast Asia, Geological Society of London Special Publication, 106, p. 247-261.

Hutchison, C.S., 2005. Geology of North-West Borneo. Elsevier, Amsterdam, 421p.

Jabbar, S. F., Amin Suyitno, D.S., Azwa Jannah, A.B., Khairul Amri, B., Basiron, J., Ayub, A. \& Madon, M., 2015. The NNG Discovery: A new oil play in the Pre-Cycle I Basement, Onshore Sarawak. Asia Petroleum Geoscience and Exhibition (APGCE) 2015, Kuala Lumpur. Proceedings and Abstracts

Johansson, M., 1999. Facies analysis of the Plateau Sandstones (Eocene to early Miocene?), Bako National Park, Sarawak, Malaysia. Journal of Asian Earth Sciences, 17, p. 233-246.

Jong, J., Kessler, F., Noon, S. and Tan, T.T.Q., 2016. Structural development, depositional model and petroleum system of Paleogene carbonate of the Engkabang-Karap Anticline, onshore Sarawak. Berita Sedimentologi, 34, p. 5-25.

JX Nippon, 2014. Engkabang West-1 Geological well completion report, $82 \mathrm{p}$. Unpublished internal report.

Kessler, F.L., 2013. The Batu Gading, Bukit Besungai Hollystone Quarry - Observations on a 
tectonically isolated carbonate sequence northeast of Long Lama, Sarawak. Warta Geologi, 39, 1, 1-4.

Kessler, F.L. and Jong, J., 2015a. Tertiary uplift and the Miocene evolution of the NW Borneo shelf margin. Berita Sedimentologi, 33, p. 21-46.

Kessler, F.L. and Jong, J., 2015b. Incision of the Baram, Limbang and Temburong river systems in fluvial gravel and conglomeratic terraces: further circumstantial evidence for the uplift of NW Borneo during the Quaternary. Geological Society of Malaysia Bulletin, 61, p. 49-57.

Kessler, F.L. and Jong, J., 2016. Paleogeography and Carbonate Facies Evolution in NW Sarawak from the Late Eocene to the Middle Miocene. Warta Geologi, 42, 1-2, p. 1-9.

Kessler, F.L. and Jong, J., 2017. Carbonate banks and ramps on the northern shore of Paleogene and Early Neogene Borneo: observations and implications on stratigraphy and tectonic evolution. Bulletin of the Geological Society of Malaysia, 63, p. 1-26.

Kessler, F.L. and Jong, J., 2018. Sandstone diagenesis: Establishing threshold temperature and depth of porosity deterioration, Penyu Basin and Tenggol Arch, offshore Peninsular Malaysia. Berita Sedimentologi, 41, p. 4-21.

Kessler, F.L., Jong, J. and Madon, M., 2020. Sedimentary record of Paleogene sequences in the Penyu and Malay Basins, offshore Peninsular Malaysia. Berita Sedimentologi, 46, p. 6-20.

Kirk, H.J.C., 1957. The geology and mineral resources of the upper Rajang and adjacent areas.

British Territories Borneo Region Geological Survey, Kuching, Memoir 8, 181p.

Kuswandaru, G.Y., Amir Hassan, M.H., Matenco, L.C., Taib, N.I. and Mustapha, K.A., 2018. Turbidite, debrite, and hybrid event beds in submarine lobe deposits of the Palaeocene to Middle Eocene Kapit and Pelagus members, Belaga Formation, Sarawak, Malaysia. Geological Journal, 54, p. 3421-3437.

Liechti, P., Roe, F.W. and Haile, N.S., 1960. The Geology of Sarawak, Brunei and the western part of North Borneo. British Territories of Borneo, Geological Survey Dept., Bull. 3, 360p.

Lunt, P., 2014. A review of the foraminiferal biostratigraphy of the Melinau Formation, Sarawak. Berita Sedimentologi, 29, p. 41-50.

Lunt, P and Madon, M., 2017. A review of the Sarawak cycles: history and modern application. Bulletin of the Geological Society of Malaysia, 63, p. 77-101.

Madon, M., 1999. Geological setting of Sarawak. In: PETRONAS, The Petroleum Geology and Resources of Malaysia, Kuala Lumpur, p. 274-290.

Maga, D., Jong, J., Madon, M. and Kessler, F.L., 2015. Fluid inclusions in quartz: Implications for hydrocarbon charge, migration and reservoir diagenetic history of the Penyu Basin and Tenggol Arch, offshore Peninsular Malaysia. Bulletin of the Geological Society of Malaysia, 61, p. 59-73.

Morley, R.J., Sanatul Salwa Hasan, Morley, H.P., Jaizan Hardi M. Jais, Amiruddin Mansor, M. Raziken Aripin, M. Hafiz Nordin and M. Helmi Rohaizar, 2020. Sequence biostratigraphic framework for the Oligocene to Pliocene of Malaysia: High-frequency depositional cycles driven by polar glaciation. Palaeogeography, Palaeoclimatology, Palaeoecology 561, 110058, $37 \mathrm{p}$.

Muller, J., 1968. Palynology of the Pedawan and Plateau Sandstone Formation (CretaceousEocene) in Sarawak, Malaysia. Micropaleontology, 14 , p. $1-37$. 
Nagarajan, R., Kessler, F.L., Jong, J., Muthuvairavasamy, R., Muhammad Abdulmajid Ali, Dayong, V., Lalitguha, S., Vusak, N.. Sivanasvaran, K. \& D. Kinanthi, D., 2020. Geochemistry of the Palaeocene-Eocene Upper Kelalan Formation, NW Borneo: Implications on palaeoweathering, tectonic setting, and provenance. Geological Journal. 2021,;p. 1-28 (in press).

Ngau, A., 1989. The geology of Batu Gading area, Middle Baram, Sarawak, Malaysia. Unpublished Bachelor of Science Thesis, University of Malaya.

Roohi, G., 1994. Biostratigraphy of the Subis Limestone, Sarawak. MSc thesis, University of Malaya.

Satyana, A. H., 2003. Accretion and dispersion of Southeast Sundaland: The growing and slivering of a continent. Proceedings of Joint Convention. The $32^{\text {nd }}$ IAGI and the $28^{\text {th }}$ HAGI Annual Convention and Exhibition, Jakarta, 31p.

Savva, D., Pubellier, M., Franke, D., ChamotRooke, N., Meresse, F. and Steuer, S., 2014. Different expressions of rifting on the South China Sea margins. Marine and Petroleum Geology, 58, p. 579-598.

Saw, B.B., Schlaich, M., Pöppelreiter, M.C., Mu. Ramkumar, Lunt, P., Vintaned, J.A.G. and Syed Haroon Ali, 2019. Facies, depositional environments, and anatomy of the Subis build-up in Sarawak, Malaysia: implications on other Miocene isolated carbonate build-ups. Facies, 65, 28 , p. $1-14$.

Tan, D.N.K, 1979. Lupar Valley, West Sarawak, Malaysia. Geological Survey of Malaysia, Report 13, p. $1-159$.
Tan, D.N.K., 1982. The Lubok Antu Melange, Lupar Valley, West Sarawak: a Lower Tertiary subduction complex. Bulletin of the Geological Society of Malaysia, 15, p. 31-46.

Tongkul, F. 1997. Sedimentation and tectonics of Paleogene sediments in central Sarawak. Bulletin of the Geological Society of Malaysia, 40, 135-155.

Uyop Said, Mohd R. Umor and Ahmad Jantan, 1996. On the lowermost palynomorphs assemblage in the Kayan Sandstone from Gunung Senggi, Bau, Sarawak, Warta Geologi, 22, 3, p. 244.

van Hattum, M.W.A., Hall, R., Pickard, A. and Nichols, G.J., 2013. Provenance and geochronology of Cenozoic sandstones of Northern Borneo. Journal of Asian Earth Sciences, 76, p. 266-282.

Wilson, M.E.J., Chang, E.E.W, Dorobek, S. and Lunt, P., 2013. Onshore to offshore trends in carbonate sequence development, diagenesis and reservoir quality across a land-attached shelf in $\mathrm{SE}$ Asia. Marine and Petroleum Geology, 45, p. 349376.

Wolfenden, E.B., 1960. The Geology and Mineral Resources of the lower Rajang Valley and adjoining areas, Sarawak. British Territories Borneo Region Geological Survey Department, Memoir 11, 167 p.

Zainol, A.A.B., Madon, M. and Abdul Jalil, M., 2007. Deep-marine sedimentary facies in the Belaga Formation (Cretaceous-Eocene), Sarawak: Observations from new outcrops in the Sibu and Tatau areas. Bulletin of the Geological Society of Malaysia, 53, p. 35-45. 